\title{
Assessment of Road Project for Accelerating Permanent Connectivity
}

\author{
Dipak Basnyat ${ }^{*}$, Buddhi Raj Joshi ${ }^{2}$ \\ ${ }^{1}$ Consultant Engineer, Infrastructure Development Office, Pokhara Metropolitan City-17, Kaski, Nepal \\ ${ }^{2}$ Lecturer, School of Engineering, Pokhara University, Pokhara Metropolitan City-30, Kaski, Nepal
}

DOI: $10.36348 /$ sjet.2020.v05i01.001

| Received: 16.01 .2020 | Accepted: 23.01.2020 | Published: 30.01 .2020

*Corresponding author: Dipak Basnyat

\section{Abstract}

Performance Assessment is the tools which give clear indication about the construction status of the project which finds out the strength and weakness of project implementation and examines the effectiveness of technical social and environmental parameters of the Road construction project. Strengthening the National Rural Transport program (SNRTP) is introduce to fulfill the aim of GON to provide all-weather road access to all Village Development Committee (VDC) by gradually upgrading the District Road Core Network (DRCN) and providing proper maintenance. Assessment of the project's measured the project output, budget, time deadlines, quality, deliverables, and specifications. The study was focus on finding out different stage, parameters, process used in road construction project and checking compliance of Technical, social and environmental parameters with prescribed design standard. Geometric parameters, road safety and maintenance, bio- engineering and plantation works, implementation on VCDP and GAP was not found as per requirements. Project was completed 18 months behind the original completion date so the project management has failure to control the time overrun.

Keywords: Road Project, Permanent Connectivity, (SNRTP), District Road Core Network (DRCN).

Copyright @ 2020: This is an open-access article distributed under the terms of the Creative Commons Attribution license which permits unrestricted use, distribution, and reproduction in any medium for non-commercial use (NonCommercial, or CC-BY-NC) provided the original author and source are credited.

\section{INTRODUCTION \\ Background}

Assessment of the project is the process of analyzing the actual, as against the projected estimates in respect of time, cost and quality specifications. Assessment includes investigation of the variances per constituent of the project objectives (and, within such constituent, major elements of variances) leading to the assessment of the overall situation. Project assessment are effective in disseminating knowledge about good practices, correcting errors in individuals' knowledge (especially their knowledge about other functions within the organization), and predicting how well alternative practices would have turned out. At the same time these reviews demonstrated several limitations. The diagnosis that took place in reviews tended to be shallow, remedies was planned only at a very superficial level, and explanations of events tended to be overly specific. Participants also made potentially misleading assumptions: for example, those unimportant problems implied unimportant causes. Nonetheless, post-project reviews are important learning mechanisms and their value seems to be underestimated by individuals who do not appreciate the need to disseminate insights throughout the organization.Project assessment gives clear indication about the construction status of the project it finds out the strength and weakness of project implementation. The project assessment is somewhat like a lessons learned activity which provides great information to practice on future project engagements. Assessment of the project's measured the project plan, budget, time deadlines, quality, deliverables, specifications, and client satisfaction. Performance assessment of Road consists of checking compliance and noncompliance of different Components of Road project.

\section{SNRTP Project}

At the end of the Fiscal year 2068/69(2011/2012), Nepal had 50,944 km of rural roads [1]. Two-thirds of rural roads are earthen and remain inaccessible during the rainy season. Blacktopped and graveled roads are poorly maintained, further affecting access. The rural transport infrastructure has been attracting around $6 \%$ of national budget (NPR 26 billion in 2011/12) which will be increasing over the years. The importance of local governments in promoting sustainable development of rural roads is being felt seriously [2]. So SNRTP project was introduce to fulfill the objective. The Government of Nepal (GON) aims to provide all- 
weather road access to all VDCs by gradually upgrading the District Road Core Network (DRCN) and providing proper maintenance with the aim of promoting economic growth, providing access to services and creating sustainable decent jobs in rural areas. Currently a large majority of roads are only fairweather and in poor condition, with a large portion of roads not trafficable. Insufficient maintenance is being carried out, further aggravating the situation.In this context, GON with support of the World Bank is implementing the SNRTP project to strengthen the DRCN with a particular emphasis on the "Maintenance First" approach. This project will furthermore cover the upgrading and rehabilitation of rural roads as well as the construction of new river crossing structures to bring the roads to an allweather maintainable standard. The project covered 36 districts with the total population of more than 14.6 million people [3].

\section{Objectives of the Project}

- The Project Development Objective (PDO) for this project is to enhance the availability and reliability of transport connectivity for rural communities in the participating districts.
- Project outcomes include (i) increased access to all weather transport connectivity for communities in participating districts; and (ii)improved reliability of rural transport infrastructure in participating districts [2].

\section{Project Component}

Component A: Institutional Strengthening and Technical Assistance

Component A will fund three categories of activities including: (A1) institutional strengthening and technical assistance; (A2) beneficiary monitoring of physical works under Component $\mathrm{B}$ of the project; and (A3) an impact study of selected project interventions.

\section{Component B: Maintenance Upgrading and Rehabilitation \\ Component B will support districts to implement physical works through two funding windows: (B1) output-based maintenance of rural transport infrastructure; and (B2) upgrading or rehabilitating rural transport infrastructure.}

SNRTP Financing

\begin{tabular}{|lll|}
\hline Funding source & Amount (USD million) & Percentage \\
\hline World Bank IDA Grant & $\$ 72.00$ & $41.0 \%$ \\
\hline World Bank IDA Credit & $\$ 28.00$ & $16.0 \%$ \\
\hline GON funding & $\$ 75.40$ & $43.0 \%$ \\
\hline Total & $\$ 175.40$ & $100.0 \%$ \\
\hline
\end{tabular}

Financing of SNRTP Project [2]

\section{OBJECTIVE OF THE STUDY}

The objectives of the study are as follow

- To assess compliance with technical, environmental and social parameter.

- To identify the gap between design and implementation of the project, recommendation for future improvement and best practices of the project.

\section{Significance of the study}

The study will critically analyze the Technical, Social and Environmental parameters for the project effectiveness after the construction of road. Identification and description of Different Technical, Social and Environmental parameters helps the fresh technical person and entrepreneur who are interested in road construction field. SNRTP project set the certain Guidelines for successfully completion of the project. From this study it will be easy to find out whether the project components were compliance or noncompliance with the approved guidelines. This study will also be helpful for concern stakeholders to know actual condition of the sub-project after the completion of the project. This Study methodology will help other similar project for performance Assessment.

\section{Limitation of the study}

- SNRTP Syangja has complete three road sub project Walling-Dumrebhanjyang, RangkholaBiruwa and Badkhola-Takshar. All this three project has same nature, the starting date, completion date, time extension, Variation order are same and exist on same day also. So my study covers one road projects (Badkhola-TaksharDelegaunda).

- Planning and budgeting section of project was not included in the study.

- Laboratory testing was not carried out for quality measurement.

\section{LITERATURE REVIEW}

General

"Managing Roads for National Integration and Socio-Economic Development" is the vision for development of roads in Nepal. The transport sector in Nepal is dominated by the road transport which accounts for almost all domestic passenger and freight movements [4]. 
Dipak Basnyat \& Buddhi Raj Joshi., Saudi J Eng Technol, Jan. 2020; 5(1): 1-24

Road network in Nepal is divided into Central Road System and Local Road System as per the National Transport Policy of the country. The Strategic Road Network (SRN) as per Department of Roads (DoR) classification is a part of the Central Road System which also includes the Asian Highway. This System is administered by the Ministry of Physical Infrastructure and Transport (MoPIT) and the implementing agency is DoR. The mission statement for the Department of Roads is "To contribute towards the betterment of living conditions of the people through effective, efficient, safe and reliable strategic road connectivity". In addition to the extension of strategic network, a considerable expansion of the local rural road network has occurred over the past 10 years, the construction of such being undertaken by a larger number of local initiatives and agencies often involving significant local participation [4]. Assessment of the project represents evaluation of the project after its completion, analyzing the actual, as against the projected estimates in respect of time, cost and quality specifications. The evaluation includes investigation of the variances per constituent of the project objectives (and, within such constituent, major elements of variances) leading to the assessment of the overall situation. Project evaluation is a systematic and objective assessment of an on-going or completed project. The aim is to determine the relevance and level of achievement of project objectives, development effectiveness, efficiency, impact and sustainability. Evaluations also feed lessons learned into the decisionmaking process of the project stakeholders, including donors and national partners.

Table-1: Evaluation method from literature review [5]

\begin{tabular}{|c|c|}
\hline Researchers & List of Indicators and Evaluation Method \\
\hline \multirow{3}{*}{$\begin{array}{l}\text { Tabish and Jha } \\
\text { [7] }\end{array}$} & Overall success : Nine-point scale \\
\hline & Anti-corruption norms: Nine-point scale \\
\hline & Financial norms: Nine-point scale \\
\hline \multirow{4}{*}{$\begin{array}{l}\text { Shahrzad Khosravi } \\
\text { [8] }\end{array}$} & Time Performance \\
\hline & Cost Performance \\
\hline & Quality Performance \\
\hline & Client Satisfaction \\
\hline \multirow{10}{*}{$\begin{array}{l}\text { Al-Tmeemy et al. } \\
\text { [9] }\end{array}$} & Quality Targets \\
\hline & Schedule \\
\hline & Budget achievement \\
\hline & Satisfaction of customer \\
\hline & Functionality \\
\hline & Meeting specification \\
\hline & Profit achievement \\
\hline & Market development \\
\hline & Reputation \\
\hline & Competitive Improvement \\
\hline \multirow[t]{5}{*}{ Ahadzie et al.[10] } & Project Cost \\
\hline & Project duration \\
\hline & Project Quality \\
\hline & Customer Satisfaction \\
\hline & Environmental impact \\
\hline \multirow{4}{*}{$\begin{array}{l}\text { Menches and Hanna } \\
{[11]}\end{array}$} & Profit $(0.583)$ \\
\hline & Realistic schedule (0.033): How realistic: $1-5$ \\
\hline & Communication (0.133): Rate how good: $1-5$ \\
\hline & Achieved budget cost (0.083): Exceed or not: Y/N \\
\hline \multirow{5}{*}{$\begin{array}{l}\text { Bryde and Robinso } \\
{[12]}\end{array}$} & Project Cost $(*)$ \\
\hline & Project Duration $(*)$ \\
\hline & Technical specification \\
\hline & Customer Satisfaction \\
\hline & Stakeholders Satisfaction $(*)$ \\
\hline \multirow{7}{*}{$\begin{array}{l}\text { Chan and Chan } \\
\text { [6] }\end{array}$} & $\begin{array}{l}\text { Time: Construction duration, Construction speed,Schedule } \\
\text { variation }\end{array}$ \\
\hline & Project cost: unit \\
\hline & Profit: net present value \\
\hline & Safety: Accident rate, EIA or ISO 14000 \\
\hline & Environmental performance: Number of complaints \\
\hline & Quality: Seven-point scale \\
\hline & Functionality: Seven-point scale \\
\hline
\end{tabular}


Quality Assurance Plan (QAP)

Quality Assurance (QA) means a process for assuring the reliability of measurement data. QA principles and practices enable you to acquire data of the type and quality you need. The quality of the data must be documented in order to be scientifically and legally defensible. The purpose of preparing the QA Project Plan is to ensure that all necessary steps are taken to acquire data of the type and quality needed. A project or study is a logical sequence of activities grouped into three categories:

\section{Planning $\rightarrow$ Implementation $\rightarrow$ Assessment}

QA Project Plan documents the planning phase and guides implementation and assessment. A QA Plan are Lists the goals and objectives of a study; Identifies the type and quality of data needed; Describes the sampling and measurement procedures needed to acquire those data and Describes the QC and assessment procedures needed to ensure that the study objectives are met [13].

\section{Extention of time (EOT)}

Delays in construction activities may give rise to a need for an application of extension of time, to provide sufficient time to complete the project. Most standard form of contract contain provisions that list out relevant events that allow a contractor to apply time extensions; the contract often expressly states that the claim should be made and dealt with timely as possible with the delaying events. Unfortunately, no specific explanation with regards to the assessment of the claim is given, and this is left to the professionals involved in the project. Often, interpretation varies depending on the experience and preference of the individual party. The absence of clear guidelines and mutual agreement between parties involved regarding the assessment of construction delay will sometimes sparks a dispute amongst them [14].

In SNRTP Project, The Project Manager shall decide whether and by how much to extend the Intended Completion Date within 21 days of the Contractor asking the Project Manager for a decision upon the effect of a Compensation Event or Variation and submitting full supporting information at least 7 days prior to the intended completion date. If the Contractor has failed to give early warning of a delay or has failed to cooperate in dealing with a delay, the delay by this failure shall not be considered in assessing the new Intended Completion Date.

\section{Variation Order (VO)}

The cost of a construction project is one of the most important factors in the construction industry. Due to many reasons, the total cost of a project can significantly vary from the initial estimated cost. The reasons could be changes in scope of work, specifications, or any other contract documents. In the construction industry, variation orders are created when changes occur. It is an official document that states the changes made into the original agreement between the client and the contractor. When a variation order is created, it brings several negative effects to both the client and the contractor [14].

\section{Liquidated damage (LD)}

In a construction context, delay liquidated damages (LDs) typically represent an agreed, fixed amount (usually a daily or weekly rate) payable by a contractor to the employer in circumstances where the contractor fails to complete the work under the contract by the date for completion specified in the contract (being either the original date for completion, or where the date has been extended in accordance with the contract, the extended date for completion). It is not unusual for the total amount of LDs to be capped at a percentage of the contract price.

The following are commonly cited as a few of the benefits to the parties in agreeing a rate of LDs as part of their contract:

It quantifies the risk of late completion and permits a contractor to properly consider the risk at the tender stage; it provides the parties with certainty; it removes the need for the employer to prove the actual damage suffered [15].

In SNRTP project the liquidated damages for the whole of the Works are 0.05 PERCENT of the final Contract Price per day and that for the Milestones is as under;

Milestone 1: $0.005 \%$ of Contract Price per day, Milestone 2: $0.025 \%$ of Contract Price per day and Milestone 3: $0.05 \%$ of Contract Price per day.

Liquidated damage for Milestone 1 will be levied until end of Milestone 2, and then only liquidated damage of Milestone 2 will be levied until end of Milestone 3, and so on. No Two liquidated damage will be applicable at one time.The maximum amount of liquidated damages for the whole Works is Ten (10) percent of Contract price.

\section{Price Adjustment}

Price adjustment is a modification made to the overall price of a contract to take account of legitimate changes in the costs of performing the contract. It is a mechanism to protect both buyers and sellers from unforeseeable input price fluctuations. This guidance note discusses price adjustment provisions for goods, works, and plant contracts. Price adjustment provisions are planned during the procurement planning and bid preparation stages. Price adjustment provisions are meant to give protection to the contractor against price escalation. Cumulative impacts of price escalation can be substantial in contracts with long delivery and completion periods. Contracts that include large, price- 
sensitive materials or commodities can also experience abrupt and significant increases in price. Price adjustment may also pass on savings to the borrower (or grant recipient) due to the downward movements in price. ADB applies a general guidance that any contract with a delivery or completion period beyond 18 months should contain an appropriate price adjustment clause. The price of some components may still vary significantly within time periods shorter than 18 months. These usually include bitumen, fuel, cement, reinforced steel, etc. Where the price of such components fluctuates over short periods of time, it is also appropriate to include a price adjustment clause, whatever the length of the contract [16].

\section{Defects liability period (DLP)}

Construction contracts usually include a defects liability period during which the Contractor is responsible for repairing or rectifying defects that appear in the works. The period usually commences upon practical completion of the works and runs for a specified time frame (sometimes also known as the Maintenance period). Under a construction contract, one of the Contractor's primary obligations is to carry out and complete the works to the standard set out in the contract. The defects liability period is intended to complement this liability by setting out how and when the Contractor must remedy defective work which becomes apparent during the defects liability period. In effect, the defects liability obligation recognizes that defects will arise in the period following completion and includes the obligation to repair those defects in the general obligation to complete the works to the required standard. The defects liability period provides a practical mechanism to the Employer for the repair or making good of defects which may not be apparent before completion, without resorting to dispute resolution. Making the Contractor responsible for carrying out the repairs is usually cheaper and more efficient than either the Employer repairing the defect itself or engaging a third party to repair the defect [17].

\section{Environment Management Plan (EMP)}

By nature of the physical activities, road constructions bring about changes in natural environment and therefore, are considered environmentally sensitive. SNRTP intends to reduce environmental problems arising from such intervention to as minimum extent as is possible. Regardless of outcome of environmental screening, each subproject shall have its site specific EMP. Therefore, all subprojects will have their site specific EMP prepared for construction, upgrading and maintenance, during detail engineering design period [18].

\section{Vulnerable Community Development Plan (VCDP)}

Vulnerable Community Development Plan (VCDP) will be prepared for the betterment of vulnerable people. The targeted beneficiaries of VCDP include mainly the following groups of people.
Severely Project Affected Persons/ Families, Marginalized groups such as indigenous community (janjati / adivasi), dalits, ethnic minorities and poorest people, Single women/ women headed households, and Landless, old aged and disabled people. The VCDP will identify the needs and priority of indigenous community and other vulnerable groups and proposes need-based programs to uplift their socioeconomic condition through appropriate training and skill transfer [1].

\section{Voluntary Donation Impact Mitigation Plan (VDIMP)}

Based on the findings of the Social screening report, the subproject specific Voluntary Donation Impact Mitigation Plans (VDIMP) will be prepared to address impacts associated with donation irrespective of the type and scale of impacts that could arise in various forms: (i) loss of land; (ii) loss of houses /structures; (iii) loss of livelihood systems/income sources; and (iv) loss of community property resources. The VDIMP presents total land of the donors, donated land and its percentage, percentage of structural damage and loss or disturbance in income source and common community property. Moreover, it presents category of land donors as less than $10 \%$ land donors, above $10 \%$ land donors whose remaining holding is above $1693 \mathrm{Sqm}$, in between 850 to $1692 \mathrm{Sqm}$ and below $849 \mathrm{Sqm}$. The VDIMP will also suggest cost effective mitigation measures, required budget as per Entitlement Matrix and detail time frame to implement all activities starting from the beginning to land ownership transfer [1].

\section{Voluntary Donation Impact Mitigation Fund (VDIMF)}

Although the Government of Nepal acquires the land as per the Land Acquisition Act for the national level projects, SNRTP will pursue the principles of limited voluntary land acquisition from owners who will be provided with some cash assistance as incentive in lieu of their contribution. In response to GoN policies of guarantying property rights and World Bank social safeguard policies, the project has devised the VDIMP to ensure some cash assistance and rehabilitation supports to project affected people of various categories even if the impacts are marginal as a result of voluntary donation. Three percent of total project cost will be c`ontributed by the project for this fund [1].

\section{Gender Action Plan (GAP)}

Although females are identified as vulnerable groups and included amongst the potential beneficiaries under the vulnerable plan, this alone does not suffice to address the deep rooted social, cultural and economic issues of females. Regardless of caste and ethnicities, females in general, suffer more than their male counterparts on various grounds warranting special treatment or mitigation measures in order to be able to sustain better livelihood. The social screening and consultations will help in 
generating information, about the issues and concerns of men and women in sub-project areas which will help project to prepare a full-fledged Gender Action Plan (GAP) [1].

\section{Occupational Safety and Health (OSH)}

"Occupational Safety "means the freedom from unacceptable risk of personal harm from, or in relation to, employment, i.e. the avoidance of accidents and incidents during the time of employment and working hours. "Occupational health" means the physical and mental wellbeing of a person and the freedom from any illness caused from, or in relation to, working conditions during the time of employment and working hours [3]. All workers and supervisory staff when on any site shall wear the basic safety clothing specified. Where additional safety equipment is required by nature of the site, then all workers and supervisory staff when on any part of that site shall use the additional equipment in addition to the basic safety clothing specified.

\section{Provision and standard of different items of work}

Sub-grade

The sub-grade is top $300 \mathrm{~mm}$ compacted layers in embankment or cutting just beneath the pavement crust. The sub-grade in embankment is compacted to a higher standard than the lower layers of the embankment. In cutting, the cut formation, which serves as the sub-grade, is treated similarly to achieve the specified density to provide a suitable foundation for the pavement [19].

\section{Sub-Base}

The material to be used for such works shall be any individual or combination of naturally occurring mechanically stable quartzite gravels, river gravels and transported gravels, or granular materials resulting from the weathering of rocks, clayey silty sand etc depending upon the approved quality and the grading. The material shall be free from organic or undesirable substances.

The grading of the material after placing and compaction shall be a smooth curve within and approximately parallel to the envelope given in Table 3 $-1(\mathrm{a})$.

The Plasticity Index shall not exceed 6\%.for sub base and shall be in the range of $6-12 \%$ for uncovered gravel layer [19].

Table-2: Grading envelope for granular sub-base materials

\begin{tabular}{|l|l|}
\hline Sieve Size (mm) & Percentage by Weight Passing the Sieve \\
\hline 63.0 & 100 \\
\hline 40.0 & $70-100$ \\
\hline 20.0 & $50-85$ \\
\hline 10.0 & $40-75$ \\
\hline 4.75 & $30-60$ \\
\hline 2.36 & $20-45$ \\
\hline 1.18 & $15-35$ \\
\hline 0.075 & $4-15$ \\
\hline
\end{tabular}

\section{Crusher Run Material (CRM) Base}

The base material for this purpose shall be crusher-run material from an approved source. The source may be as-dug materials from a hill side, or river bed gravel, or a rock quarry or alluvial plain fields. The material from the approved source shall be run from the crusher to before getting approval for the use as Crusher Run Material (CRM) [1].

\section{Grading}

The grading of the material after placing and compaction shall be within and approximately parallel to the envelope given in Table 2.3. To determine the specific grading requirements, tests shall be conducted before and after the material has been mixed and spread out.

Table-3: Grading envelope for crusher run material

\begin{tabular}{|l|l|}
\hline Sieve Size ( mm ) & \% Passing by Weight \\
\hline 50 & 100 \\
\hline 40 & $75-100$ \\
\hline 31.5 & $42-75$ \\
\hline 20 & $25-60$ \\
\hline 10 & $15-45$ \\
\hline 4.75 & $12-37$ \\
\hline 2.36 & $6-25$ \\
\hline 0.6 & $5-12$ \\
\hline 0.075 & $3-12$ \\
\hline
\end{tabular}




\section{Otta Seal}

Otta seal consist essentially of a $16-30 \mathrm{~mm}$ thick bituminous surfacing constituted of an admixture of graded aggregate ranging from natural gravel to crushed rock in combination with relatively soft (Low viscosity) binders with or without sand seal cover. This type of surfacing contrasts the single sized crushed aggregate and relatively hard (High viscosity) binders used in conventional surface dressing e.g. chip seals.

\section{Binder spray rates}

The binder) spray rates in hot condition for unprimed base/sub-base course shall be as per Table 4 9(h) below

Table-4: Bituminous binder spray rate

\begin{tabular}{|c|c|c|c|c|c|}
\hline & \multirow{3}{*}{$\begin{array}{c}\text { Open } \\
1.6\end{array}$} & \multirow{3}{*}{$\begin{array}{c}\text { Medium } \\
1.7\end{array}$} & \multicolumn{2}{|c|}{ Dense } \\
\hline & & & & \multirow{2}{*}{$\begin{array}{c}\text { AADT } \\
<\mathbf{1 0 0}\end{array}$} & \multirow{2}{*}{$\begin{array}{c}\begin{array}{c}\text { AADT } \\
>\mathbf{1 0 0}\end{array} \\
1.7\end{array}$} \\
\hline \multirow{2}{*}{ Double } & $1^{\text {st }}$ layer $(*)$ & & & & \\
\hline & $2^{\text {nd }}$ layer $(*)$ & 1.5 & 1.6 & 2.0 & 1.9 \\
\hline \multirow{2}{*}{$\begin{array}{c}\text { Single, } \\
\text { with a sand } \\
\text { cover seal }\end{array}$} & $\begin{array}{l}\text { Crusher dust or } \\
\text { coarse river sand }\end{array}$ & 0.9 & 0.8 & & 0.7 \\
\hline & $1^{\text {st }}$ layer $(*)$ & 1.6 & 1.7 & 2.0 & 1.9 \\
\hline \multicolumn{2}{|c|}{ Single $(*)$} & 1.7 & 1.8 & 2.0 & 1,9 \\
\hline Maintenance & reseal(single) & 1.5 & 1.6 & 1.8 & 1.7 \\
\hline
\end{tabular}

\section{Sand Seal}

The Materials, method of construction and requirements are for the construction of sand seal. A sand seal means an application of bituminous binder covered with aggregates as specified hereunder. The binder shall be a medium-curing cut-back MC- 800 or MC-3000 or K1-60 cationic emulsion as specified in the Bill of Quantities. The aggregate shall consist of sand, or fine screenings free from organic matter, clay and other deleterious materials. The fines (passing a 0.425 $\mathrm{mm}$ sieve) shall be non-plastic. The grading shall be as specified in the Table $4-8(a)$.

Table-5: Grading of Aggregate

\begin{tabular}{|l|l|}
\hline Sieve $(\mathbf{m m})$ & Percentage passing by weight \\
\hline 10.00 & 100 \\
\hline 4.75 & $70-90$ \\
\hline 2.36 & $45-70$ \\
\hline 0.60 & $15-35$ \\
\hline 0.15 & $0-2$ \\
\hline
\end{tabular}

The rate of spray of binder shall be $1.4 \mathrm{Lit} / \mathrm{m}^{2}$ for MC 3000 cut-back bitumen and $1.6 \mathrm{Lit} / \mathrm{m}^{2}$ for Emulsion, $60 \%$ cationic. The rate of spread of the fine aggregate shall be $13-19 \mathrm{~kg} / \mathrm{m}^{2}$. [18]

\section{Relevant Policies of Government of Nepal}

Public Road Act, 1974: The Act prohibits the construction of permanent structures (buildings) within road Right of Way (RoW). If road projects temporarily require land and/or other properties during construction, rehabilitation and maintenance, compensation is determined by the Chief District Officer (CDO). Provisions are also detailed for compensation for the extraction of construction materials.
Environmental Protection Act, 1997 and Environmental Protection Regulations, 1997: According to the EPA 1997, all development projects, including roads, should first be screened using criteria that are based on project type, size, location and cost, stipulated in the Regulation to determine the level of environmental assessment required (whether IEE or EIA or none). Usually, small projects such as rehabilitation of rural roads are not expected to cause significant environmental damage and require only minor environmental assessment.

Forest Act, 1993 and Forest Regulation, 1995: The road projects need to comply with the provisions of forest Act and Regulation when it requires the use of forestland for road construction/improvements. Clause number 68 (1) allows implementation of development project of national priority in forested area, if it does not pose significant adverse impact to environment and if there are no other alternatives, after approval of government (District Forest Office - DFO) and local forest authority (eg; Community Forestry User Groups).

National Park and Wildlife Conservation Act, 1972: This act prohibits any action that could be damaging to the park including; cutting of trees and other plants, any kind of residential structures, quarrying of materials, change in watercourse, etc. Activities prohibited in protected areas includes; hunting, damage or removal of forest products, grazing, mining, digging earth or any other similar material, block or divert river systems flowing through the park, construction or possession of house, huts or other structures,. Any intervention within National Park and Wildlife Conservation Area requires permission from Ministry of Forest, Soil and Water Conservation after recommendation from Department of National Parks and Wildlife Conservation. 
Land Acquisition Act, 1977 and Land Acquisition Regulations, 1969: The Land Acquisition Act 1977 and the Land Acquisition Regulation 1969 clearly outline the procedures of land acquisition and compensation for public purposes. The act states that, if the government has already used the land for public purposes in the agreement of land owner then it is not required to follow acquisition process but can determine compensation as per the act (Section 26). Section 27 of the act clearly states that land for public purposes can be acquired through negotiation and in such case procedure laid down by the act do not have to be followed. Therefore, section 26 and 27 are applicable for obtaining land for the project.

Soil and Watershed Conservation Act, 1982: For the conservation and management of watersheds of Nepal, the Soil and Watershed Conservation Act, 1982 was enacted. Construct and maintain dam, embankment, terrace improvements, diversion channels and retaining walls; Under Section 10 of the Act, Watershed Conservation Officer has authority to grant permission to construct dams, drainage ditches, canals, cut privately owned trees, excavate sand, boulders and soil, discharge solid waste, and establish industry or residential areas within any protected watershed.

Labour Act, 2048 (1992) (first Amendment, 15 Magh 2054/ Jan.28, 1998): This Act in chapter -5 describes the Provisions Relating to Health and Safety of labours that a proprietor shall make to his employee. The Proprietor shall make the arrangements of clean and healthy working environment, arrangements of necessary preventive personal devices for protection of health from adverse any other source, to make provisions for sufficient supply of pure potable water during the working hours, to make provisions for separate toilets for male and female workers or employees at convenient place; necessary protective means shall have to be arranged for the protection of eyes and other organs of the workers and employees from injuries likely to be caused by dust or pieces while working in the Enterprise.
Child Labor (Prohibition and Regulation) Act, 2056 B.S. (June21, 2000 A.D.): This Act prohibits engaging child labour (below 16 years) in factory, mines and other risky works. This act along with others defines the construction enterprises as one of risky works.

Labour Rules, 2050 (1993): In chapter-3 of this rule describes that there will be no discrimination in remuneration to male or female worker or employee for engaging them in the works of the same nature of functions. This chapter also dictates regarding provision of compensation against injury, Compensation in case of grievous hurt resulting in physical disability, Compensation in case of death of any workers/ or employee.

\section{RESEARCH METHODOLOGY Methodology}

Everyone uses information to make decisions about the future. If the information is accurate, there is a high probability of making a good decision. However, if the information is inaccurate, our ability to make a correct decision is diminished. It is true that better information leads to better decision. Information can be either primary or secondary. Primary data refers to information collected for the specific purpose at hand. On the other hand, secondary data refers to information that already exists to be used for another purpose. In the course of our research, we have made use of both primary and secondary data. Secondary data has been in the form of books, journals and articles from the internet. Our measuring instrument to assess primary data is field data verification. There are different ways to get primary information. Some of them are: personal questionnaires, talking with people, telephone surveys, E-mail and internet surveys, experiments, focus groups, observation among others.

\section{Study area}

Badkhola Takshar-Dulegaunda road of SNRTP sub-projects in Syangja district is the study area of my research.

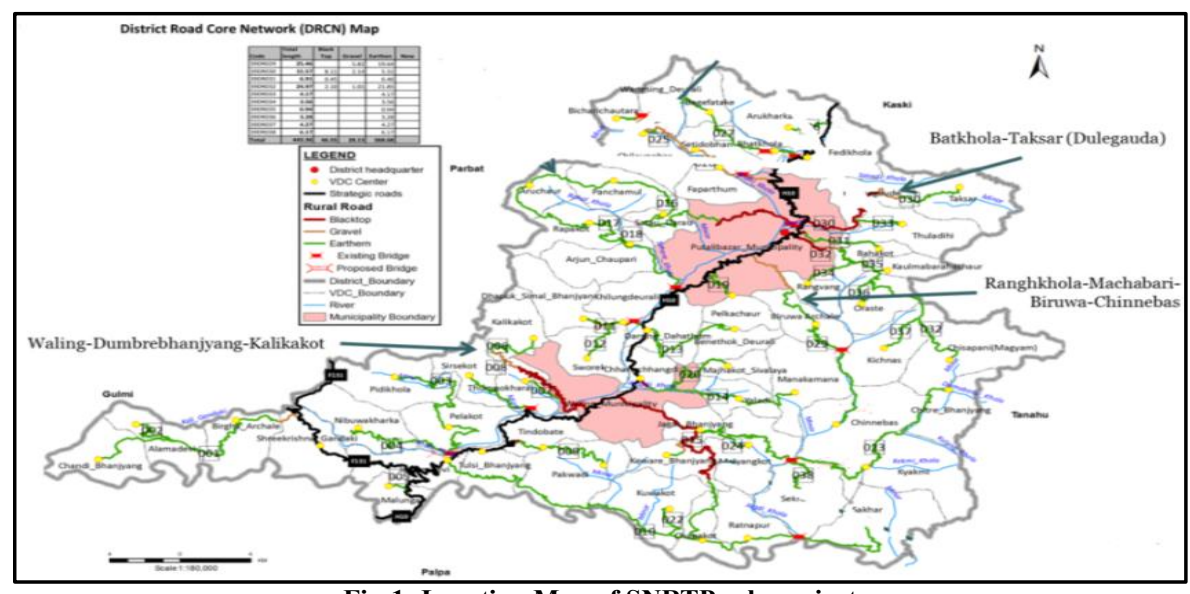

Fig-1: Location Map of SNRTP sub-project 
Syangja District is located in Gandaki Zone of the Western Development Region of Nepal. It borders with Tanahu district to the East, Gulmi and Palpa districts to the West, Parbat and Kaski districts to the North, and Palpa district to the South. The district headquarter is Putalibazar, located at an altitude of 850 m. The district has 9 Rural Municipality and 4 Municipality. The total land area of the district is about 1164 square kilometre within latitude $27^{\circ} 52^{\prime} \mathrm{N}$ to $28^{\circ} 13^{\prime} \mathrm{N}$ and longitude $83^{\circ} 27^{\prime} \mathrm{E}$ to $84^{\circ} 46^{\prime} \mathrm{E}$. Syangja district has an estimated road network of 1095
Kilometre, including $105.94 \mathrm{~km}$ of Strategic Roads managed by DOR and $443.36 \mathrm{~km}$ of District Core Road Network managed by Syangja DDC and $546.04 \mathrm{~km}$ of village roads managed by the VDCs. The District Core Road Network (DRCN) consists of a total of 38 district roads with a total length of $443.36 \mathrm{Km}$. Out of this total length there is $10.5 \%$ black topped, $7 \%$ gravelled and $82.5 \%$ earthen road surface. In terms of road serviceability there is only $17.58 \%$ of road length is all weather and remaining $82.42 \%$ of road length is fairweather.

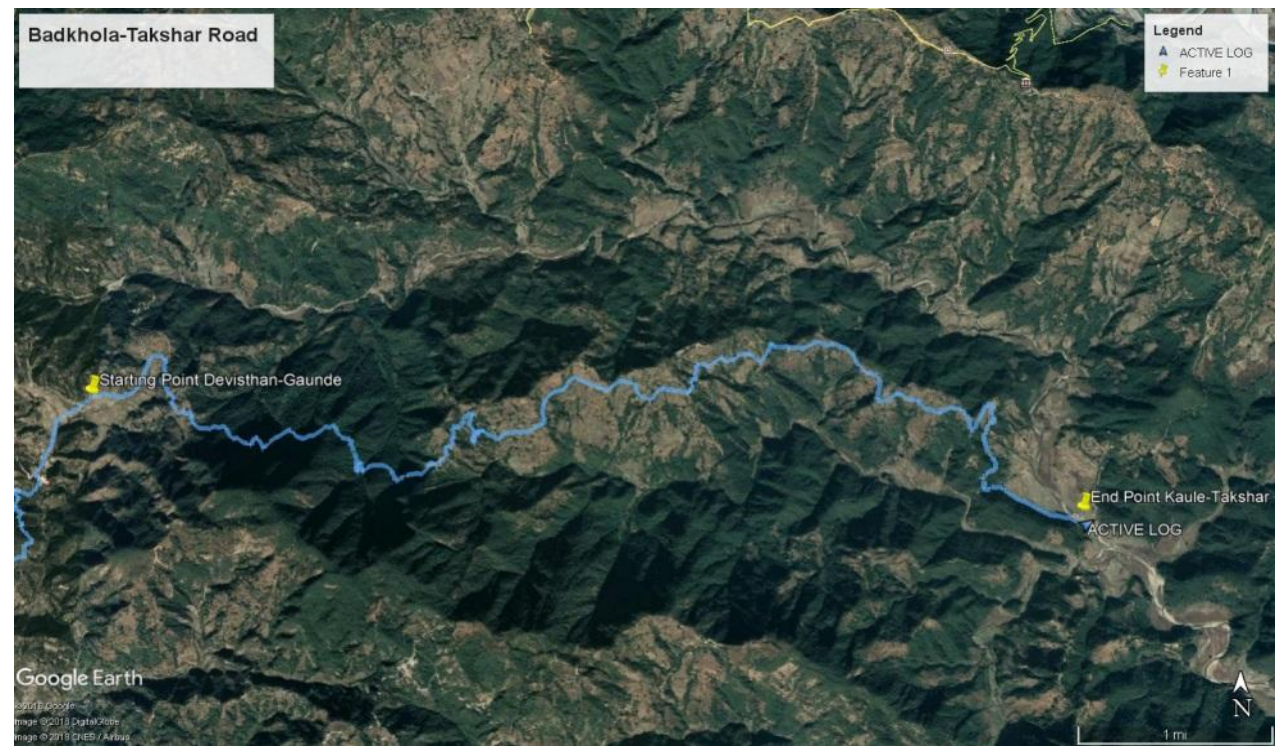

Fig-2: Study area of Badkhola-Takshar Road (Source: Google map, 2018)

The Badkhola-Takshar Road having total length 20.6 KM starting from Badkhola bazar to Kaule. Badhkhola-Taksar-Dulegaunda road is the part of the road connecting Badhkhola bazzar at Putalibazzar Municipality of Syangja district link from Siddhartha Highway. The section is starts from Devisthan (Ch: 8+000, Putalibazzar Municipality ) and ends at Taksar ,kaule settalement (Ch 18+000, Putalibazzar Municipality )The DTMP code of this road is (39DR030). Total length of this section is $10.00 \mathrm{~km}$. The passing settlements are: Devisthan, Dhadkhelne, Thuladihi, Govinde Bhanjyang, Kaule, Taksar.

The socio-economic condition is Moderate in the sub-project area. Most of the people depend on agriculture. A few are engaged in the labor, services and small business activities. There are some small market centers in some part of the corridor. Around 13,796 populations reside along the subproject zone of influence. Brahman, Chhetri, Magar, Gurung and Dalit have occupied most of land.

\section{DATA COLLECTION}

The data was collected through primary and secondary data collection method.

\section{Primary Data}

The primary data are collected through mainly two methods:

- Field survey and observation

- Recorded documents.

\section{Field Survey and observation}

From the field survey of total $10 \mathrm{KM}$ road starting from Devisthan $(\mathrm{CH} 8+000)$ to Kaule $(18+000)$ following data is observed:

The Road Gradient; Radius of Curve; Carriageway; Super elevation; Retaining structures; Pavement condition; Crossing structure; Bio engineering and plantation works; Quarry site and tipping site management and Road safety and maintenance status.

\section{RECORDED DOCUMENTS}

Documents recorded in district technical office syangja from starting to completion phase of the project are collected. They are:

The Procurement document; Survey design and drawing; Lab test report; Quality assurance plan; Letter issued and forward during construction period; Environment and social repor; Field visit report; VO and EOT documents and Payment Certificates. 


\section{Secondary Data}

Secondary data are collected through Different project documents, Journal, Books etc. that are: The DOR Norms and Specification; DOLIDAR Norms and Specification; Nepal Road Standard 2070; SNRTP Project operation Manual (POM); Project Appraisal Documents (PAD); Environment and social Management Framework (ESMF) and Quality Control Handbook for Rural Road Construction and Maintenance (Volume II).

\section{DATA ANALYSIS}

From the data collected from primary and secondary sources, are divided into three parameters. They are (i) Technical Parameters; (ii) Social Parameters and (iii) Environmental Parameters.

Details analysis of above parameters was done by comparing these parameters into project guidelines and specification. Technical parameters was compared with Project operation manual published by SNRTP project and standard specification of DOR and Social and Environmental parameters was compared with Environmental and social management framework (ESMF) published by SNRTP project.

After Analysis of different parameters of the project, critical review of all these parameters was done from Expert (Client, consultant, Contractor and concern stakeholders) and score given to each and every parameter of the project. For scoring separate sheet was distributed to the expert where different parameters of the project are include and score range is specified from $0-10$. Spider charts is used to visualize graphically the project performance. Excel spreadsheet is commonly used for developing the charts, which plot the values of each performance indicator along a separate axis.

Table-6: Assessment Parameters and evaluation criteria

\begin{tabular}{|l|l|l|}
\hline S.N & Parameters & Score \\
\hline 1 & Technical parameters & 10 \\
\hline 2 & Social Parameters & 10 \\
\hline 3 & Environmental Parameters & 10 \\
\hline Evaluation Criteria & Level of Evaluation \\
\hline Poor & less than 2 \\
\hline Marginal & $2-4$ \\
\hline Satisfactory & $4-6$ \\
\hline Good & $6-8$ \\
\hline Very Good & Greater than 8 \\
\hline
\end{tabular}

\section{CHAPTER 4: RESULT AND DISCUSSION INTRODUCTION}

This chapter presents the detail assessment of technical, environmental and social parameters of the project. Compliance with these parameters was verified from project document analysis and field verification. After Analysis of parameters, critical review were done from Expert (Client, consultant, Contractor) and score will be given to each and every parameter and finally Spider charts was drawn to visualize the project performance.

\section{Salient feature of the project}

The name of the Sub Project is BadhkholaTaksar-Dulegaunda Road of Syangja District of Nepal. Total Length with Chainage is $22.40 \mathrm{~km}(0+000-$ $22+400)$. The Proposed Length with Chainage is $10 \mathrm{~km}$ (8+000-18+000). The Covered VDCs/municipality and Settlement are Putalibazar Municipality, Devisthan, Govinde Bhanjyang, Dhadkhelne, Thuladihi, Taksar, Kaule settlement, Land use feature along the stretch cultivated land \& Settlements. DTMP/DRCN Code 39DR030, Contract Identification Number: SNRTPSYA-W-NCB-28.01-UG-070-071, Major Work/major intervention. The road improvement work includes horizontal curve improvement; embankment construction, water management and drainage improvement; otta seal with sand seal cover and other EMP works, DPR Approval Date 2070/03/10(24-June, 2013), Approved Cost Estimate NPR 76,641,703, No objection on Bid Document is made on 2070/10/06(20-jan-2014), Bid Notice Publication Date 2070/10/13(27-Jan-2014) in Nagarik Daily, Bid Opening Date 2070/11/14(26-Feb 2014), Bid evaluation finalisation Date is 2071/01/04(17-April-2014), Name of Contractor is M/S Rasuwa-Gajindra $\mathrm{J} / \mathrm{V}$ with address Putalibazzar-1, Syangja, Contract signing Date 2071/02/12(26-May 2014), Date of Validity of Performance Security is 2071/02/11 (25-May-2014), 2073/08/25(7-May-2016), Date of Valitdity of Insurance 2073/01/28(10-May. 2016), Original Contract Amount NPR 76,318,182.39, \% Below of Above (+/-) $0.42 \%$, Contract amount after VO NPR 83,942,484.94, Original Intended Completion Date 18 months after, agreement date is 2072/08/10(26-Nov, 2015), Comletion Date after EOT-1 is 2073/03/25(9July, 2016), Comletion Date after EoT-2 is 2073/12/18(31-March,2017), Completion Date after EoT-3 is 2074/02/06(20-May-2017), Completed date is 2074/02/14(28-May,2017) (DLP Certificate has been Issued). 


\section{Technical Parameters}

Gradient

Normally hill rural road connect base point hill to top of hill or vice versa. So hill road requires frequent ascending and descending. For continuous rising or falling ruling gradient determine the rate of those action. The maximum length of providing such gradient is normally limited to $150 \mathrm{~m}$ as stated by Nepal Road Standard. The value of prescribed maximum gradient for feeder road is limited to $12 \%$ given by NRS 2070 . Table 9 shows the observed value of maximum gradient at different section of road.

Table-7: Observed Gradient in sampled section

\begin{tabular}{|c|c|c|c|c|c|c|}
\hline \multirow{2}{*}{ S.N } & \multirow{2}{*}{ Sample section } & \multicolumn{3}{|c|}{ Observed maximum gradient } & \multirow{2}{*}{$\begin{array}{l}\text { Maximun } \\
\text { Gradient as } \\
\text { per NRS } \\
\end{array}$} & \multirow{2}{*}{$\begin{array}{l}\text { Gradient }+/- \\
\text { than standard } \\
\text { gradient }\end{array}$} \\
\hline & & Chainage & Length & Measurement & & \\
\hline 1 & $8+000$ to $9+000$ & $8+960$ to $9+000$ & 40 & $12 \%$ & $12 \%$ & $0 \%$ \\
\hline \multirow{2}{*}{2} & \multirow{2}{*}{$9+000$ to $10+000$} & $9+240$ to $9+300$ & 60 & $11.5 \%$ & $12 \%$ & $-0.5 \%$ \\
\hline & & $9+340$ to $9+380$ & 40 & $8.0 \%$ & $12 \%$ & $-4 \%$ \\
\hline 3 & $10+000$ to $11+000$ & $10+340$ to $10+370$ & 30 & $14.0 \%$ & $12 \%$ & $2 \%$ \\
\hline \multirow{6}{*}{4} & \multirow{6}{*}{$11+000$ to $12+000$} & $11+340$ to $11+420$ & 80 & $10.4 \%$ & $12 \%$ & $-2 \%$ \\
\hline & & $11+420$ to $11+460$ & 40 & $16.8 \%$ & $12 \%$ & $5 \%$ \\
\hline & & $11+580$ to $11+640$ & 60 & $12.3 \%$ & $12 \%$ & $0 \%$ \\
\hline & & $11+640$ to $11+720$ & 80 & $9.0 \%$ & $12 \%$ & $-3 \%$ \\
\hline & & $11+720$ to $11+780$ & 60 & $8.2 \%$ & $12 \%$ & $-4 \%$ \\
\hline & & $11+900$ to $11+940$ & 40 & $11.5 \%$ & $12 \%$ & $0 \%$ \\
\hline \multirow{3}{*}{5} & \multirow{3}{*}{$12+000$ to $13+000$} & $12+260$ to $12+340$ & 80 & $15.6 \%$ & $12 \%$ & $4 \%$ \\
\hline & & $12+360$ to $12+400$ & 40 & $6.0 \%$ & $12 \%$ & $-6 \%$ \\
\hline & & $12+560$ to $12+640$ & 80 & $13.6 \%$ & $12 \%$ & $2 \%$ \\
\hline \multirow{4}{*}{6} & \multirow{2}{*}{$13+000$ to $14+000$} & $13+140$ to $13+200$ & 60 & $12.8 \%$ & $12 \%$ & $1 \%$ \\
\hline & & $13+460$ to $13+520$ & 60 & $13.0 \%$ & $12 \%$ & $1 \%$ \\
\hline & & $13+520$ to $13+580$ & 60 & $18.3 \%$ & $12 \%$ & $6 \%$ \\
\hline & & $13+620$ to $13+680$ & 60 & $11.2 \%$ & $12 \%$ & $-1 \%$ \\
\hline \multirow{3}{*}{7} & \multirow{3}{*}{$15+000$ to $16+000$} & $15+300$ to $15+360$ & 60 & $14.8 \%$ & $12 \%$ & $3 \%$ \\
\hline & & $15+520$ to $15+560$ & 40 & $14.3 \%$ & $12 \%$ & $2 \%$ \\
\hline & & $15+940$ to $16+000$ & 60 & $17.5 \%$ & $12 \%$ & $6 \%$ \\
\hline \multirow{8}{*}{8} & \multirow{3}{*}{$16+000$ to $17+000$} & $16+080$ to $16+140$ & 60 & $13.0 \%$ & $12 \%$ & $1 \%$ \\
\hline & & $16+180$ to $16+220$ & 40 & $10.5 \%$ & $12 \%$ & $-2 \%$ \\
\hline & & $16+240$ to $16+360$ & 120 & $15.2 \%$ & $12 \%$ & $3 \%$ \\
\hline & & $16+420$ to $16+500$ & 80 & $17.6 \%$ & $12 \%$ & $6 \%$ \\
\hline & & $16+540$ to $16+620$ & 80 & $11.4 \%$ & $12 \%$ & $-1 \%$ \\
\hline & & $16+640$ to $16+720$ & 80 & $7.2 \%$ & $12 \%$ & $-5 \%$ \\
\hline & & $16+860$ to $16+920$ & 60 & $13.0 \%$ & $12 \%$ & $1 \%$ \\
\hline & & $16+960$ to $17+040$ & 80 & $18.8 \%$ & $12 \%$ & $7 \%$ \\
\hline \multirow{3}{*}{9} & \multirow{3}{*}{$17+000$ to $18+000$} & $17+060$ to $17+120$ & 60 & $14.0 \%$ & $12 \%$ & $2 \%$ \\
\hline & & $17+260$ to $17+320$ & 60 & $16.6 \%$ & $12 \%$ & $5 \%$ \\
\hline & & $17+380$ to $17+420$ & 40 & $17.2 \%$ & $12 \%$ & $5 \%$ \\
\hline
\end{tabular}

Observed gradient at each kilometer measured shows that out of 31 section $10(32.25 \%)$ section have gradient within the range i.e up to $12 \%$ (NRS 2070) and rest $21(67.75 \%)$ section have gradient more than the maximum.

\section{Radius of horizontal curve}

The vehicle length is related to the turning radius. Longer the vehicle length higher value of radius is needed in turning. The horizontal alignment should be a smooth and as directed as possible while responsive to the topography. Table 10 shows the observed value of radius of horizontal curve at different section. 
Dipak Basnyat \& Buddhi Raj Joshi., Saudi J Eng Technol, Jan. 2020; 5(1): 1-24

\begin{tabular}{|c|c|c|c|c|c|c|}
\hline \multirow{3}{*}{$\begin{array}{l}\mathbf{S} . \\
\mathbf{N}\end{array}$} & \multirow{3}{*}{ Chainage } & \multirow{3}{*}{$\begin{array}{l}\begin{array}{l}\text { Observed } \\
\text { minimum radius }\end{array} \\
\text { Chainage }\end{array}$} & \multirow[b]{3}{*}{ Measurement } & \multirow{3}{*}{$\begin{array}{l}\text { Minimum } \\
\text { radius as per } \\
\text { NRS(m) }\end{array}$} & \multirow{3}{*}{$\begin{array}{l}\text { Radius +/- } \\
\text { than } \\
\text { standard }\end{array}$} & \multirow{3}{*}{ Remarks } \\
\hline & & & & & & \\
\hline & & & & & & \\
\hline 1 & $8+000$ to $9+000$ & $8+740$ & 16.66 & 10 & 6.66 & \\
\hline \multirow{5}{*}{2} & \multirow{2}{*}{$9+000$ to $10+000$} & $9+180$ & 7.42 & 10 & -2.58 & \\
\hline & & $9+300$ & 10.94 & 10 & 0.94 & \\
\hline & & $9+680$ & 13.61 & 10 & 3.61 & \\
\hline & & $9+760$ & 16.02 & 10 & 6.02 & \\
\hline & & $9+900$ & 13.54 & 10 & 3.54 & \\
\hline 3 & $10+000$ to $11+000$ & $10+320$ & 7.47 & 10 & -2.53 & \\
\hline \multirow[t]{4}{*}{4} & $11+000$ to $12+000$ & $11+300$ & 13.09 & 10 & 3.09 & \\
\hline & & $11+580$ & 11.39 & 10 & 1.39 & \\
\hline & & $11+760$ & 5.90 & 10 & -4.10 & \\
\hline & & $11+960$ & 5.25 & 10 & -4.75 & \\
\hline \multirow[b]{3}{*}{5} & \multirow{3}{*}{$12+000$ to $13+000$} & $12+040$ & 7.77 & 10 & -2.23 & \\
\hline & & $12+260$ & 14.50 & 10 & 4.50 & \\
\hline & & $12+520$ & 14.61 & 10 & 4.61 & \\
\hline \multirow[b]{2}{*}{6} & \multirow{2}{*}{$13+000$ to $14+000$} & $13+200$ & 7.15 & 10 & -2.85 & \\
\hline & & $13+240$ & 9.09 & 10 & -0.91 & \\
\hline \multirow[b]{3}{*}{7} & \multirow{3}{*}{$14+000$ to $15+000$} & $14+040$ & 16.27 & 10 & 6.27 & \\
\hline & & $14+620$ & 12.44 & 10 & 2.44 & \\
\hline & & $14+980$ & 20.64 & 10 & 10.64 & \\
\hline \multirow[b]{2}{*}{8} & \multirow{2}{*}{$15+000$ to $16+000$} & $15+320$ & 13.29 & 10 & 3.29 & \\
\hline & & $15+860$ & 12.33 & 10 & 2.33 & \\
\hline \multirow[b]{3}{*}{9} & \multirow{3}{*}{$16+000$ to $17+000$} & $16+300$ & 12.96 & 10 & 2.96 & \\
\hline & & $16+460$ & 9.30 & 10 & -0.70 & \\
\hline & & $16+860$ & 7.70 & 10 & -2.30 & \\
\hline \multirow[b]{2}{*}{10} & \multirow{2}{*}{$17+000$ to $18+000$} & $17+340$ & 9.03 & 10 & -0.97 & \\
\hline & & $17+480$ & 6.80 & 10 & -3.20 & \\
\hline
\end{tabular}

Radius of curve 10m (NRS 2070) is the minimum radius when the design speed is $20 \mathrm{kmph}$ and maximum super elevation provided is $10 \%$. From the study of $10 \mathrm{KM}$ road at different 26 section 11 (42.3\%) section was found smaller than the minimum requirement.

\section{Carriageway}

Width of the carriage way depends on the width of the traffic lane and number of lane. In a rural road with feeder road standard, the minimum value of carriageway is $5.5 \mathrm{~m}$ i.e. intermediate lane. The carriageway in a curve section is greater than in straight section due to more space required in curve to turn front and rear part of vehicle. The carriage way with is 4.25 $\mathrm{m}$ in Badkhola-Takshar project. For the site verification, sample is taken at every $300 \mathrm{~m}$ interval. Table 11 shows the observed carriage way width of the road. 
Dipak Basnyat \& Buddhi Raj Joshi., Saudi J Eng Technol, Jan. 2020; 5(1): 1-24

Table-9: Carriage way width in sample section:

\begin{tabular}{|c|c|c|c|c|c|}
\hline \multirow{2}{*}{ S.N } & \multirow{2}{*}{$\begin{array}{l}\text { Sampled } \\
\text { Chainage }\end{array}$} & \multicolumn{2}{|c|}{ Observed Carriageway (m) } & \multirow{2}{*}{$\begin{array}{l}\text { Minimum carriageway } \\
\text { as per design }(\mathrm{m})\end{array}$} & \multirow{2}{*}{$\begin{array}{l}\text { Carriageway }+/- \\
\text { than standard }\end{array}$} \\
\hline & & Chainage & Measurement & & \\
\hline \multirow{3}{*}{1} & \multirow{3}{*}{$8+000$ to $9+000$} & $8+300$ & 4 & 4.5 & -0.5 \\
\hline & & $8+600$ & 4 & 4.5 & -0.5 \\
\hline & & $8+900$ & 4.5 & 4.5 & 0 \\
\hline \multirow{3}{*}{2} & \multirow[b]{3}{*}{$9+000$ to $10+000$} & $9+300$ & 7 & 4.5 & 2.5 \\
\hline & & $9+600$ & 4.5 & 4.5 & 0 \\
\hline & & $9+900$ & 4.7 & 4.5 & 0.2 \\
\hline \multirow{3}{*}{3} & \multirow{3}{*}{$\begin{array}{l}10+000 \\
11+000\end{array}$} & $10+300$ & 4.1 & 4.5 & -0.4 \\
\hline & & $10+600$ & 4.7 & 4.5 & 0.2 \\
\hline & & $10+900$ & 5 & 4.5 & 0.5 \\
\hline \multirow{3}{*}{4} & \multirow{3}{*}{$\begin{array}{l}11+000 \\
12+000 \\
\end{array}$} & $11+300$ & 6.5 & 4.5 & 2 \\
\hline & & $11+600$ & 4.3 & 4.5 & -0.2 \\
\hline & & $11+900$ & 4.5 & 4.5 & 0 \\
\hline \multirow{3}{*}{5} & \multirow{3}{*}{$\begin{array}{l}12+000 \\
13+000\end{array}$} & $12+300$ & 4.5 & 4.5 & 0 \\
\hline & & $12+600$ & 5 & 4.5 & 0.5 \\
\hline & & $12+900$ & 4.5 & 4.5 & 0 \\
\hline \multirow{3}{*}{6} & \multirow{3}{*}{$\begin{array}{l}13+000 \\
14+000\end{array}$} & $13+300$ & 4.1 & 4.5 & -0.4 \\
\hline & & $13+600$ & 3.9 & 4.5 & -0.6 \\
\hline & & $13+900$ & 5.1 & 4.5 & 0.6 \\
\hline \multirow{3}{*}{7} & \multirow{3}{*}{$\begin{array}{l}14+000 \\
15+000\end{array}$} & $14+300$ & 4.45 & 4.5 & -0.05 \\
\hline & & $14+600$ & 4.4 & 4.5 & -0.1 \\
\hline & & $14+900$ & 4.7 & 4.5 & 0.2 \\
\hline \multirow[t]{3}{*}{8} & \multirow{3}{*}{$\begin{array}{l}15+000 \\
16+000\end{array}$} & $15+300$ & 4.8 & 4.5 & 0.3 \\
\hline & & $15+600$ & 4.5 & 4.5 & 0 \\
\hline & & $15+900$ & 4.4 & 4.5 & -0.1 \\
\hline \multirow{3}{*}{9} & \multirow{3}{*}{$\begin{array}{l}16+000 \\
17+000\end{array}$} & $16+300$ & 5 & 4.5 & 0.5 \\
\hline & & $16+600$ & 4.2 & 4.5 & -0.3 \\
\hline & & $16+900$ & 4.5 & 4.5 & 0 \\
\hline \multirow{3}{*}{10} & \multirow{3}{*}{$\begin{array}{l}17+000 \\
18+000\end{array}$} & $17+300$ & 4.5 & 4.5 & 0 \\
\hline & & $17+600$ & 4.5 & 4.5 & 0 \\
\hline & & $17+900$ & 4.5 & 4.5 & 0 \\
\hline
\end{tabular}

From the field verification it was observed that 10 (33.33\% of total observed) section was found minimum carriage way width than standard.

\section{Super Elevation}

Super elevation is provided in a horizontal curve. The normal value of super elevation provided is $7 \%$ as per NRS. NRS recommended on a hill road not bound by snow a maximum super elevation up to 10 percent can be given. Minimum value of super elevation should be equal to the rate of camber of the pavement. Camber is $2.5 \%$ on bituminous, $4 \%$ on graveled and $5 \%$ on earthen surface as per NRS. The standard super elevation range is provided between $2.5 \%$ to $10 \%$ (NRS 2070) and compared accordingly which are given in following table. 
Dipak Basnyat \& Buddhi Raj Joshi., Saudi J Eng Technol, Jan. 2020; 5(1): 1-24

\begin{tabular}{|c|c|c|c|c|c|c|}
\hline \multirow{3}{*}{ S.N } & \multicolumn{6}{|c|}{ Table-10: Super elevation and its acceptance in sampled section: } \\
\hline & \multirow{2}{*}{$\begin{array}{l}\text { Sampled } \\
\text { section }\end{array}$} & $\begin{array}{l}\text { Observed } \\
\text { super elevation }\end{array}$ & & \multirow{2}{*}{$\begin{array}{l}\text { Super elevation } \\
\text { range as per NRS }\end{array}$} & \multirow{2}{*}{$\begin{array}{l}\text { Acceptable (yes) or } \\
\text { not acceptable (No) }\end{array}$} & \multirow[t]{2}{*}{ Remarks } \\
\hline & & Chainage & Measurement & & & \\
\hline 1 & $\begin{array}{ll}8+000 & \text { to } \\
9+000 & \end{array}$ & $8+740$ & $2.3 \%$ & $2.5 \%$ to $10 \%$ & No & \\
\hline \multirow[t]{5}{*}{2} & $\begin{array}{ll}9+000 & \text { to } \\
10+000 & \end{array}$ & $9+180$ & $1.8 \%$ & $2.5 \%$ to $10 \%$ & No & \\
\hline & & $9+300$ & $2.8 \%$ & $2.5 \%$ to $10 \%$ & Yes & \\
\hline & & $9+680$ & $3.8 \%$ & $2.5 \%$ to $10 \%$ & Yes & \\
\hline & & $9+760$ & $3.3 \%$ & $2.5 \%$ to $10 \%$ & Yes & \\
\hline & & $9+900$ & $2.1 \%$ & $2.5 \%$ to $10 \%$ & $\mathrm{No}$ & \\
\hline 3 & $\begin{array}{ll}10+000 & \text { to } \\
11+000\end{array}$ & $10+320$ & $2.3 \%$ & $2.5 \%$ to $10 \%$ & No & \\
\hline \multirow[b]{4}{*}{4} & \multirow{4}{*}{$\begin{array}{l}11+000 \\
12+000\end{array}$} & $11+300$ & $3.0 \%$ & $2.5 \%$ to $10 \%$ & Yes & \\
\hline & & $11+580$ & $2.0 \%$ & $2.5 \%$ to $10 \%$ & $\mathrm{No}$ & \\
\hline & & $11+760$ & $2.4 \%$ & $2.5 \%$ to $10 \%$ & No & \\
\hline & & $11+960$ & $2.2 \%$ & $2.5 \%$ to $10 \%$ & $\mathrm{No}$ & \\
\hline \multirow[b]{3}{*}{5} & \multirow{3}{*}{$\begin{array}{l}12+000 \text { to } \\
13+000\end{array}$} & $12+040$ & $1.8 \%$ & $2.5 \%$ to $10 \%$ & $\mathrm{No}$ & \\
\hline & & $12+260$ & $3.5 \%$ & $2.5 \%$ to $10 \%$ & Yes & \\
\hline & & $12+520$ & $2.0 \%$ & $2.5 \%$ to $10 \%$ & $\mathrm{No}$ & \\
\hline \multirow[b]{2}{*}{6} & \multirow{2}{*}{$\begin{array}{ll}13+000 & \text { to } \\
14+000 & \\
\end{array}$} & $13+200$ & $2.7 \%$ & $2.5 \%$ to $10 \%$ & Yes & \\
\hline & & $13+240$ & $1.1 \%$ & $2.5 \%$ to $10 \%$ & No & \\
\hline \multirow[b]{3}{*}{7} & \multirow{3}{*}{$\begin{array}{l}14+000 \text { to } \\
15+000\end{array}$} & $14+040$ & $2.0 \%$ & $2.5 \%$ to $10 \%$ & No & \\
\hline & & $14+620$ & $4.5 \%$ & $2.5 \%$ to $10 \%$ & Yes & \\
\hline & & $14+980$ & $1.4 \%$ & $2.5 \%$ to $10 \%$ & $\mathrm{No}$ & \\
\hline \multirow[b]{2}{*}{8} & \multirow{2}{*}{$\begin{array}{l}15+000 \\
16+000\end{array}$} & $15+320$ & $4.2 \%$ & $2.5 \%$ to $10 \%$ & Yes & \\
\hline & & $15+860$ & $2.0 \%$ & $2.5 \%$ to $10 \%$ & $\mathrm{No}$ & \\
\hline \multirow[b]{3}{*}{9} & \multirow{3}{*}{$\begin{array}{l}16+000 \\
17+000\end{array}$} & $16+300$ & $2.0 \%$ & $2.5 \%$ to $10 \%$ & $\mathrm{No}$ & \\
\hline & & $16+460$ & $1.2 \%$ & $2.5 \%$ to $10 \%$ & $\mathrm{No}$ & \\
\hline & & $16+860$ & $2.6 \%$ & $2.5 \%$ to $10 \%$ & Yes & \\
\hline \multirow[b]{2}{*}{10} & \multirow{2}{*}{$\begin{array}{ll}17+000 & \text { to } \\
18+000\end{array}$} & $17+340$ & $2.3 \%$ & $2.5 \%$ to $10 \%$ & No & \\
\hline & & $17+480$ & $1.9 \%$ & $2.5 \%$ to $10 \%$ & No & \\
\hline
\end{tabular}

Data shows that only $9(34.6 \%)$ section of observed road curve are found to be constructed and maintained with satisfactory super elevation range. Remaining $17(65.4 \%)$ section are not as per requirements.

\section{Contract Procurement}

Detail project report (DPR) was prepared by district technical office syangja and submitted to project management unit (PMU) butwal for approval. DPR was approved on 2070/10/03. The approved cost of DPR was NPR 76,641,703. No objection letter (NOL) on bid documents was received on 2070/10/06. After NOL received procurement process was started. Detail of contract procurement of Badkhola-Takshar road was shown in table below. 
Dipak Basnyat \& Buddhi Raj Joshi., Saudi J Eng Technol, Jan. 2020; 5(1): 1-24

Table-11: Compliance status of Contract Procurements:

\begin{tabular}{|c|c|c|c|c|c|}
\hline SN & Description & Requirements & $\begin{array}{l}\text { Compliance } \\
\text { Status } \\
\text { (Yes/No) } \\
\end{array}$ & $\begin{array}{l}\text { Date of } \\
\text { Compliance }\end{array}$ & Remarks \\
\hline \multirow[t]{4}{*}{1} & Contract Bidding & 1.1 Bid notices published date & Yes & $13-10-70$ & \\
\hline & & 1.2 Pre bid meeting & Yes & $04-11-70$ & $\begin{array}{l}10 \text { days before } \\
\text { submission of bid }\end{array}$ \\
\hline & & 1.3 Bid opening & Yes & $14-11-70$ & $\begin{array}{l}30 \text { days after } \\
\text { Notice published }\end{array}$ \\
\hline & & 1.4 Bid evaluation & Yes & $04-01-71$ & $\begin{array}{l}\text { Within } 90 \text { days } \\
\text { after bid opening }\end{array}$ \\
\hline \multirow[b]{2}{*}{2} & \multirow{2}{*}{ Conrtact Signing } & $\begin{array}{l}\text { 2.1 Contract Signing within } 7 \text { days of Letter of } \\
\text { Acceptance }\end{array}$ & Yes & 26-Мау-14 & \\
\hline & & $\begin{array}{l}2.2 \text { Work Order given for commencement of } \\
\text { work within } 15 \text { days of contract signing date. }\end{array}$ & Yes & 02-Jun-14 & \\
\hline \multirow[b]{2}{*}{3} & \multirow{2}{*}{$\begin{array}{l}\text { Performance } \\
\text { Security }\end{array}$} & $\begin{array}{l}2.1 \text { Performance security submit before } \\
\text { contract signing }\end{array}$ & Yes & 25-Мау-14 & \\
\hline & & $\begin{array}{l}\text { 2.2 Performance security Validity, DLP+30 } \\
\text { days }\end{array}$ & Yes & 10-Dec-16 & \\
\hline 4 & $\begin{array}{l}\text { Contract Start } \\
\text { Date }\end{array}$ & 7 days afer issuing work order & No & 09-Jun-14 & \\
\hline 5 & $\begin{array}{l}\text { Possession of the } \\
\text { Site }\end{array}$ & 15 Days after contract Start Date & No & 24-Jun-14 & \\
\hline 6 & Insurance & $\begin{array}{l}\text { (a) for loss or damage to the Works, } \\
\text { Plantand Materials: } \\
\text { Minimum cover: } 115 \% \text { of the Contract } \\
\text { amount. } \\
\text { Maximum deductible: NRs. } 100,000.00 . \\
\text { (b) For loss or damage to Equipment. } \\
\text { Minimum cover: NRs. } 2,000,000.00 \\
\text { Maximum deductible: NRs. } 25,000.00 \\
\text { (c) For loss or damage to property } \\
\text { Minimum cover: NRs. 1,000,000.00 } \\
\text { Maximum deductible: NRs, } 25,000.00 \\
\text { (d) for personal injury or death: } \\
\text { (i) of the Contractor's employees: As per the } \\
\text { Labour Act of Nepal. } \\
\text { (ii) For Employers'/Engineers' staff: NRs. } \\
500,000.00 \\
\text { (iii) of other people of third parties: NRs. } \\
500,000.00\end{array}$ & Yes & 26-Jun-14 & \\
\hline 7 & Advance Payments & & & & \\
\hline 7.1 & $\begin{array}{l}\text { First Installment- } \\
5 \%\end{array}$ & $\begin{array}{l}\text { After submission of Unconditional bank } \\
\text { Guarantee }\end{array}$ & Yes & $13-06-71$ & \\
\hline 7.2 & $\begin{array}{l}\text { Second } \\
\text { Installment-5\% }\end{array}$ & $\begin{array}{l}\text { After submission of Unconditional bank } \\
\text { Guarantee along with approval of joint } \\
\text { construction survey, QAP, revised work } \\
\text { schedule, full mobilisation of all key personnel, } \\
\text { labor and equipment, insurance policies, } \\
\text { establishment of labor camp and OSH } \\
\text { provision. }\end{array}$ & Yes & $17-08-71$ & \\
\hline
\end{tabular}

From the analysis of Procurement document, the procurement process was completed as per public procurement act 2064 .

\section{Survey and design}

The detailed engineering survey, design and cost estimate for upgrading of Badkhola-Takshar road has been prepared by District technical office syangja. The road alignment starts from $8+140$ and end at $18+140$.

Nepal rural road standard (2055) with second revision, DOLIDAR is followed to design the road. The road falls under the category of district road core network as per NRRS as it connects village and district headquarters as well as SRN. Accordingly the design parameters and standards are considered for the road design. The total right of way adopted is $20 \mathrm{~m}$ (10m on either side). Adopted roadway width is 4.25 which includes carriageway and shoulder, and formation width is 5.25 including drain.

After the agreement of contract joint construction survey was carried out by contractor with presence of client. Contractor prepared and approved the survey and design report from client. 
Design of road was carried out by SW/DTM 2006 computer software developed by SOFTWEL (P) ltd. Nepal and executes the Plan, Profile and Crosssection according to NRS 2070 which also gives the quantity of earthwork excavation, Quantity of retaining wall, crossing structure, quantity of sub-grade, sub-base and base. The approval of the design, drawing and quantity from client is 2071/03/10 (24-June, 2014).

\section{QUALITY OF WORKS \\ (a) Quality of Structure \\ Masonry works}

Requirements are, the masonry work shall be laid to lines, level, and dimensions as per approved design drawing; the stones shall be durable, angular, sound, hard, and free from iron cracks or other defects; the stone shall not absorb water more than 5 per cent. The specific gravity of the stone shall not be less than 2.50.; During construction, the Contractor shall make and test mortar cubes at the rate of three cubes for every $10 \mathrm{~m} 3$ of masonry to assess the strength subject to a minimum of 3 cubes samples for aday's work; At least 3 set of tests for stone and sand shall be conducted for every source.; The mortar used in work shall have the strength not less than 5 $\mathrm{N} / \mathrm{mm} 2$ or $7.5 \mathrm{~N} / \mathrm{mm} 2$ at 28 days as specified.

\section{Findings}

Total 1342.71 cubic meter masonry work was done in Badkhola-Takshar road. Among them 162 cum used for pipe culvert works, 628.45 cum for drain works, 408.49 cum for retaining wall and 143.77 cum for dry causeway works. From the observation it was found that masonry works was proper line and level. Material used (stone, cement and sand) was properly tested and approved. From the visual inspection no any defects were found in masonry structure. From the lab record data total 135 no of compressive strength test was done which meets the testing frequency as per specification. Test of Specific gravity and water absorption of stone, test of sand and cement meets the frequency requirements.

\section{Gabion Works}

Requirements are Stones used for filling the gabion boxes or mattresses shall be clean, hard, sound, un weathered and angular rock fragments or boulders. The length of any stone shall not exceed three times its thickness. The smallest dimension of any stone shall be at least twice that of the longer dimension of the mesh of the crate. All wires used in the manufacturing crates and diaphragms, binding and connecting lids and boxes shall be galvanized with an heavy coating of zinc by an electrolytic or hit dip galvanizing process. In walls, gabion boxes shall be placed such that vertical joints are not continuous, but staggered. Before filling with stone, gabions shall be anchored at one end or side and stretched from the opposite end or side by inserting temporary bars and levering them forward, The top and bottom shall be kept stretched by tensioning with tie wires attached to an anchorage or equivalent approved method until the gabion has been filled.

The gabion wire shall be tested for mass, uniformity and adhesion of zinc coating and tensile strength of the wire.

\section{Findings}

983 Cubic Meter of gabion wall used at various chainage along the road was found. The line and level were maintained according to design drawing. No any defects were seen from the observation. Quarry of Stone used for the gabion was tested and approved. The specific gravity and water absorption was complying with the specification. Gabion wire used is machine made hexagonal mesh wire, complying with the NS 163-2045. Contractor submit sample of gabion boxes for necessary test. Two set of gabion wire test was done, from the test data it shows that adhesion of zinc coating and tensile strength was compliance with the specification.

\section{Pipe Culvert}

Requirements are, Reinforced concrete pipes shall comply with the requirements of NS 80/2042 or IS 458:1988. Trenches shall be kept free from water until the pipes are installed and the joints have hardened. The pipes shall be laid true to line and level, commencing from the outfall. Pipes shall be laid such that each one is in contact with the bed throughout the length of barrel. The pipes shall be laid closely together against each other so as to obtain tight joints. Catch pits, headwalls, wing walls, aprons and other ancillary works shall be constructed in accordance with the details shown on the Drawing. The Contractor shall submit manufacturer's test certificates for each lot of pipes supplied. The test results shall meet the requirements of the relevant Specifications.

\section{Findings}

Tota 182 running meter pipe was used at various chainage along the road.30 dia-15 no, 60 dia127 no, 90 dia-40 no, each of $2.5 \mathrm{~m}$ length reinforced concrete pipe was used. The pipe supplied meets the requirements of NS 80/2042. Bed of pipe was laid on layer of fine granular materials $100 \mathrm{~mm}$ thick after bottom of the pipe was excavated and joints of pipe were done by cement mortar. The cover of pipe was provided $600 \mathrm{~mm}$ over the crown of the culvert by suitable materials.Catch pits and headwall was done from stone masonry according to the drawing. In most places Outlet of the pipe was not provided suitable structure for proper water management. The Contractor submits manufacturer's test certificates for each lot of pipes supplied. The test results meet the requirements of the Specifications. 


\section{Concrete works}

Requirements are, Batching and mixing plants shall be complying with the requirements of IS 1791 and capable of producing a uniform distribution of the ingredients throughout the mass. Concrete shall be fully compacted throughout the full extent of the placed layer. It shall be thoroughly worked against the formwork and around any reinforcement and other embedded i tem, without displacing them. The test of Cement, sand, aggregate should be done before starts of works. Three sets of cube made for testing compressive strength of concrete for every 6 cum.

\section{Findings}

978.2 cubic meter concrete class M15 was used for Drain PCC and Causeway works and 32.02 cum concrete class M10 was used for pipe culvert head wall and catch pit bed. From the record of lab it was observed that Materials use for concrete (cement, fine aggregate, coarse aggregate) were tested and approved from the lab.Total 204 no of compressive strength test was done from 1010 cum of concrete and 5 test was done for FI, LAA, and ACV.

\section{(b) Quality Assurance Plan (QAP)}

QAP was prepared and submitted by contractor according to project format. The Contractor shall implement the Quality Control in compliance with the approved QAP.

Approved Quality assurance plan (QAP) was found and also revised QAP after variation order was submitted by contractor. The QAP shall include the following;

The Detail work procedure; Design drawing and specification; Organization chart with allocated role and responsibility; Work schedule; Material management schedule; Material testing schedule; Material extraction schedule for different sources; Spoil dumping location and Reinstatement of quarry site.

\section{(c) Construction methodology}

Daily diary: Found partially compliance, few months maintain the works record on diary. Working Drawing: Not Compliance, No record was found of approval of working drawing before starts of work., Material stock record: No record was found; Labor record: No record was found; Accident Record: No record was found; Use of engineering instrument for line and layout of structure: Compliance and Used of level machine for line and layout.

\section{(d) Laboratory Operation}

As per provision lab was established in DTO office syangja, all the test was done from this lab throughout the project. But the equipment is not sufficient for carryout all the test.The list of equipment's available in the lab is listed below.
The Lab test equipment's should be calibrated every year for obtaining accurate result; it was found that the all the machine was calibrated. The manpower is not sufficient for smooth operation of lab. There are one Lab in charge and one lab assistant, lab assistant must be 2 no and training for lab staff is not enough. There is provision of establishment of site laboratory by contractor. But no lab was established by contractor. All the lab operation was conducted from client lab. The test result was found properly recorded in file. From the test data it was found that the entire necessary test was conducted following the standard testing procedure. And test result shows that all the test of the material meets their requirement.

\section{Contract Management}

It was observed that well contract management was adopted at the site.

\section{Financial Management}

The Central Project Coordination Unit (CPCU) is responsible for overall budgeting. For each financial year the CPCU will prepare an annual budget indicating the activities to be carried out in the current financial year and the related budget, as well as the budget spent in the past financial year. District technical office (DTO) is responsible for Operate SNRTP Financial Transactions, Set up accounting system and maintain accounting records in accordance with requirements of the WB and the Government, submit Implementation Progress Reports (IPR) to the PMU; comprising Financial Management Reports (FMR) and Procurement Management Reports (PMR) on trimester basis within 15 (Fifteen) days from the end of trimester.

From the analysis of financial documents following activities were found. The first mobilization payment was made on date September 19, 2014 for amount NPR. 33, 51, 000 and second mobilization was made on December 03, 2014 for amount NPR 33, 51, 000. Mobilization was done after four months from the contract agreement. Nine running bill wwere made for the payment of works to the contractor on different date. No payment delay was found from the record. The Financial audit was done every year no Arrear (Beruju) Record was found from badkhola-Takshar road. Timely reporting to PMU and CPCU for the budget so that no budget scarcity during the contract period.

\section{Liquidity damage (LD)}

Three (3) milestones had been kept in the contract for monitoring the progress of the works. The provision of liquidated damage had also been provided in the contract in case of not achieving these milestones on the scheduled date; with $0.005 \%, 0.025 \%$ and $0.05 \%$ of initial contract amount for 1st, 2nd and 3rd milestones respectively. Contractor was not able to achieve second and third revised milestone except first 
milestone hence Liquidated damage for second and third milestone has been deducted in this contract.

\section{Variation order (VO)}

Due to the following major reason about 9.99 $\%$ variation order was issued to the contractor. Increase in width of roadway excavation and protection/check wall, water management works as per site condition reviewed in construction survey.

Table-12: Summary of the variation Order

\begin{tabular}{|l|l|l|l|l|l|}
\hline $\begin{array}{l}\text { Original Cost } \\
\text { Estimate } \\
\text { ( Including VAT) }\end{array}$ & $\begin{array}{l}\text { Original Contract } \\
\text { Amount } \\
\text { ( Including VAT) }\end{array}$ & $\begin{array}{l}\text { Revised Contract } \\
\text { Amount (NRs) } \\
\text { ( Including VAT) }\end{array}$ & $\begin{array}{l}\text { Variation Amount } \\
\text { (NRs) } \\
\text { ( Including VAT) }\end{array}$ & $\begin{array}{l}\text { Percentage } \\
\text { Change in } \\
\text { Contract } \\
\text { Amount }\end{array}$ & Remarks \\
\hline $\mathbf{7 6 , 6 4 1 , 7 0 3 . 0 0}$ & $\mathbf{7 6 , 3 1 8 , 1 8 2 . 3 9}$ & $\mathbf{8 3 , 9 4 2 , 4 8 4 . 9 4}$ & $\mathbf{7 , 6 2 4 , 3 0 2 . 5 5}$ & $\mathbf{+ 9 . 9 9}$ & \\
\hline
\end{tabular}

\section{Extension of time (EOT)}

In Badkhola-Takshar road three time extensions (541 days) were done due to following major reason are:

The Affected days due to 2072/01/12 (25April-2015) Earthquake \& its aftershock; Increase in quantity in earthwork in excavation in roadway; Strike and lack of fuel; Affected days due to fuel crises beyond 2073/08/11 (26-Nov-2016) and active monsoon, unfavourable time for otta-seal, national festival.

\section{Monitoring, Supervision and reporting}

Monitoring, supervision and reporting of Badkhola-Takshar road was found from the monthly progress report, site instruction record, and site visit record on Construction Site Monitoring (CSM)
Application. Continuous monitoring of works was from consultants where the project deploys technical, social and environment consultant for monitoring, supervision and reporting. For supervision works from contractor side only one sub-engineer handle the project most of the contract period. At the end of the project during pavement work one engineer recruit for supervision and monitoring but has less experience. Contractor mention his key personal (Contract manager-1, Site engineer-1, lab technician-1, sub engineer-1 and supervisor-3) in approved quality assurance plan (QAP) and contract documents also. But contractor has failed to comply monitoring and supervisory staff as per requirements.

\section{Road safety and maintenance}

In Badkhola-Takshar road following items of road safety works were performed.

Table-13: Road safety works in Badkhola-Takshar Road

\begin{tabular}{|l|l|l|l|l|}
\hline S.N & Safety works & As per Contract (No) & Actual on site (No) & Remarks \\
\hline 1. & Traffic sign & 30 & 28 & \\
\hline 2. & Kilometer stone & 9 & 9 & \\
\hline 3. & 5 Km stone & 2 & 2 & \\
\hline 4. & Delinator post & 250 & 221 & \\
\hline
\end{tabular}
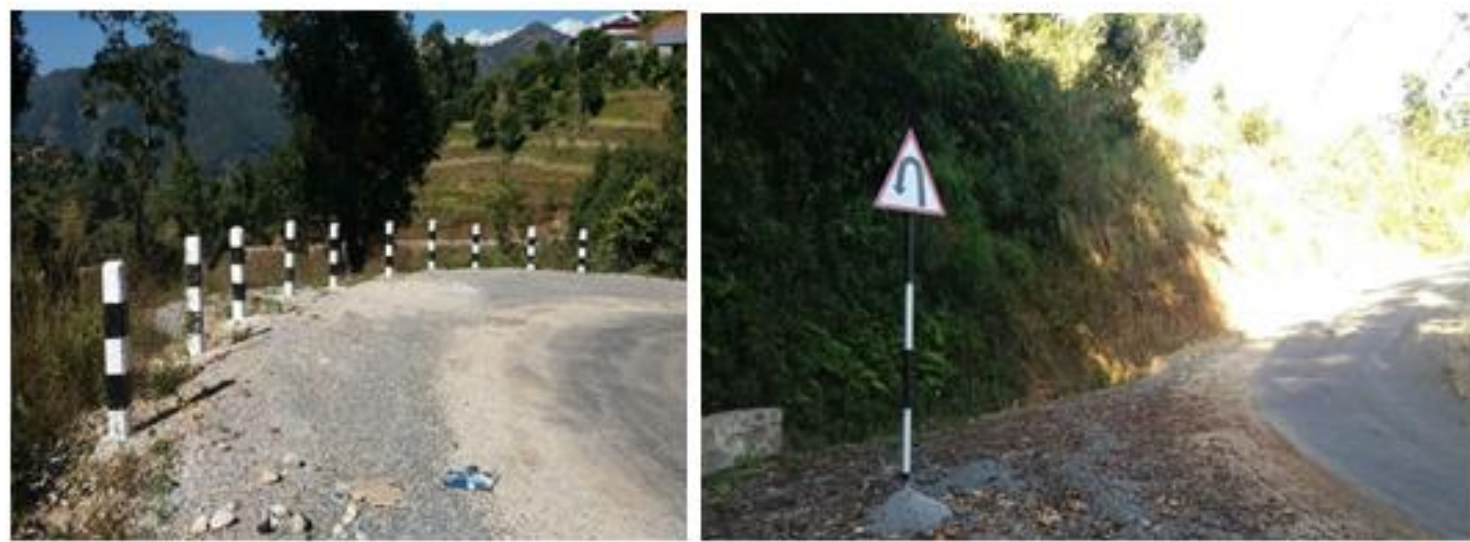

Fig-3: Installation of Traffic Sign and Delineator post

Traffic Sign are provided to control and guide traffic and to promote road safety. Traffic signal should be properly installed along the road so as to ensure a smooth flow of traffic as well as to caution the roads users about the possible hurdles and inconveniences. 
Total cost allocation for road safety was NPR $5,07,000$ which was only $0.7 \%$ of total estimated cost. So cost allocated for road safety works was not sufficient. The quantity estimate of traffic sign, delineator post was also not sufficient, from the field observation it was found that these are required in many place. Road maintenance after the construction was found very poor. Road needs routine and recurrent maintenance. The surface deterioration rate is increase day by day; landslide from the slop blocked the drain in many place and water flow over the road.
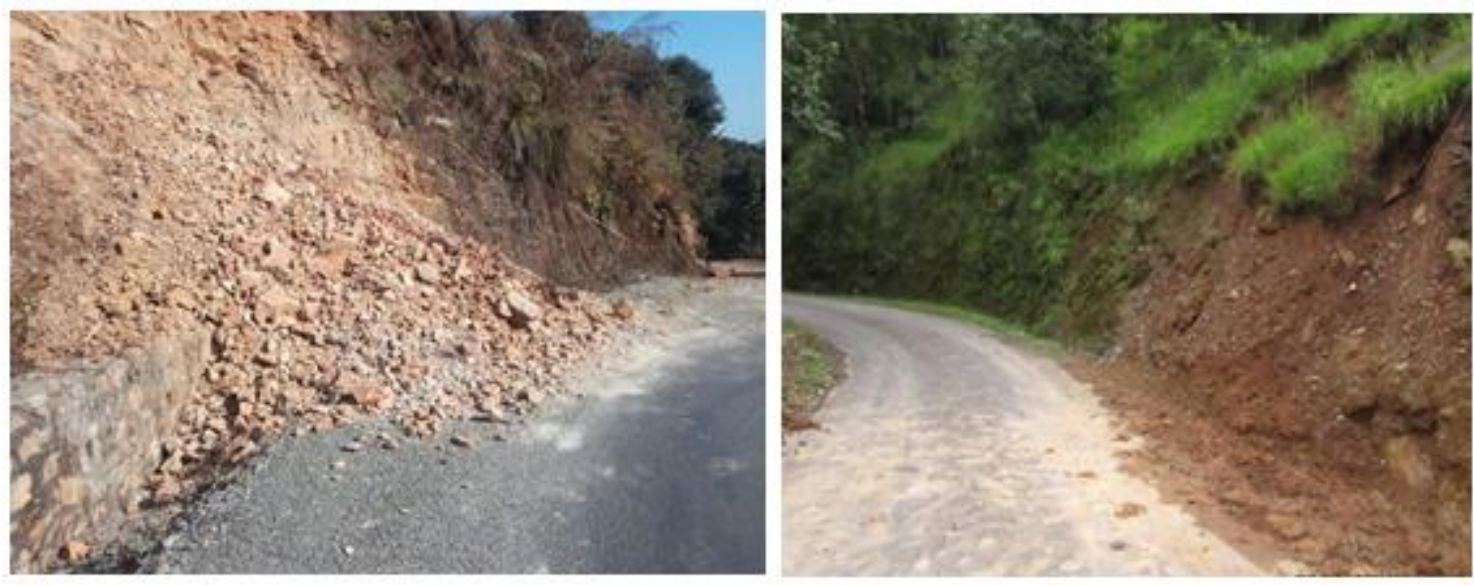

Fig-4: Landslide blocked the drain

\section{Analysis of Environmental parameters}

The detail environmental cost and EMP implementation of Badkhola-Takshar road;

Table-14: Detail of EMP Implementation

\begin{tabular}{|l|l|l|}
\hline S.N & Name of Road & Badkhola-Takshar \\
\hline 1 & Major EMP Works & $\begin{array}{l}\text { Bioengineering works, House Protection, } \\
\text { Relocation, Drain management ,Labor camp } \\
\text { Management,Occupational health and safety }\end{array}$ \\
\hline 2 & EMP amount as per DPR, NPR & $472,927.00$ \\
\hline 3 & EMP cost as per Contract, NPR & $298,200.00$ \\
\hline 4 & EMP cost under user(LRUC), NPR & $5,025,565.59$ \\
\hline 5 & Total EMP cost, NPR & $5,323,765.59$ \\
\hline 6 & $\%$ of EMP cost against total contract & $6.34 \%$ \\
\hline 7 & Paid EMP Amount & \\
\hline 7.1 & Contractor, NPR & $1,31,313.00$ \\
\hline 7.2 & LRUC, NPR & $26,72,572.07$ \\
\hline
\end{tabular}

The environmental screening and Site-specific Environmental Management Plan (EMP) of BadhkholaTaksar-Dulegaunda Road was found and approved as provision in Environmental and Social Management Framework (ESMF). The environmental impact includes dust emission, noise pollution, use of bitumen, occupational health \& safety, road safety measures. The impacts were minimized with the implementation of suggested measures forwarded by site- specific Environmental Management Plan.

\section{Quarry site selection and management}

Quarry site location as per EMP was at chainage $11+700$ and $12+500$. But contractor preferred road side cutting as quarry site. Materials were extracts from Quarry Chainage $11+700$. But Quarry site management and restoration was not done. Slope stabilization work, erosion control measure were not done as provision in ESMF.

\section{Tipping site and its management}

Following tipping site was identified for proper and safe disposal of soil.

Table-15: Tipping Site Location in EMP

\begin{tabular}{|l|l|l|l|}
\hline Chainage & Land use & Area & Remarks \\
\hline $8+450$ & Barren Land & 400 & \\
\hline $9+500$ & Barren Land & 400 & \\
\hline $10+860$ & Jungle area & 150 & \\
\hline $12+550$ & Gulley & 500 & \\
\hline $13+920$ & Cultivated land & 625 & \\
\hline $16+900$ & Barren Land & 650 & \\
\hline
\end{tabular}


Adequate number of tipping site was not found because of hilly area. But above approved tipping site were also not fully utilized for soil disposal. Haphazard disposal of spoil were found without considering environmental impact. Spoil management plan (i.e Toe wall, shrub plantation, slope maintaining etc) were not done on tipping site.

\section{Crusher site management}

Crusher was established at $\mathrm{CH}: 12+600$. Land agreement documents between contractor and concern stakeholder were found. Crusher site was located far from habitant area. Restatement of crusher site was not properly done. Crusher site was located near the road so vehicle movement was disturbed.

\section{OSH and Labor camp}

From analysis of site instruction, progress report, letter forwarded to contractor during construction period and consultation with stakeholders, the actual condition of $\mathrm{OSH}$ and labor camp on Badkhola-Takshar road was performed well.

\section{Analysis of Social Parameters}

The socio-economic condition is Moderate in Badkhola-Takshar road project area. Most of the people depend on agriculture. A few are engaged in the labor, services and small business activities. There are some small market centers in some part of the corridor. Brahman, Chhetri, Magar, Gurung and Dalit have occupied most of land. Summary of social safeguard implementation was attached in Annex -5.

\section{Formation of Committee}

Table-16: Committee formation

\begin{tabular}{|l|l|l|l|l|l|l|}
\hline Level & \multicolumn{6}{|l|}{ Committees } \\
\hline District Level & DRCC & GHC & ADC & LAC & DMC & OSH \\
\hline Local Level & LRUC & VRCC & & & & \\
\hline
\end{tabular}

As provision in ESMF, following committees were formed

Voluntary Donation Impact Mitigation Plan (VDIMP)

Table-17: Status of VDIMP

\begin{tabular}{|c|c|c|c|c|c|}
\hline Road Name & $\begin{array}{l}\text { Total } \\
\text { Affecte } \\
\text { d Plots }\end{array}$ & $\begin{array}{l}\text { Total } \\
\text { Affected } \\
\text { Land (Sqm) }\end{array}$ & $\begin{array}{l}\text { Assistance } \\
\text { provided } \\
\text { plots (in no.) }\end{array}$ & $\begin{array}{l}\text { Ownership Transfer } \\
\text { Completed } \quad \text { (plot } \\
\text { no.) }\end{array}$ & $\begin{array}{l}\text { Total Assistance NRs. } \\
\text { (Land+ } \\
\text { Structure+Livlihood loss) }\end{array}$ \\
\hline Badkhola-Takshar & 159 nos & 22215 Sqm. & 159 nos & 159 nos & Nrs.2,00,000 \\
\hline
\end{tabular}

Social Management Plan

Social Management plan was prepared on the basis of $3 \%$ of total DPR cost.

Table-18: Status of Social Management Plan

\begin{tabular}{|l|l|l|l|l|l|}
\hline Description of work & Documents Status & Budget & Training Provided & Remarks \\
\hline VDIMP & Prepared & $2,00,000.00$ & Assistance distribution to voluntarily land donors & Completed \\
\hline VCDP & Prepared & $2,89,545.47$ & $\begin{array}{l}\text { Sewing \& cutting, Beekeeping, } \\
\text { Vegetable farming and House wiring training etc. }\end{array}$ & $\begin{array}{l}\text { Yet not } \\
\text { completed }\end{array}$ \\
\hline GAP (Gender Action Plan) & Prepared & $315,909.00$ & $\begin{array}{l}\text { Sewing \& cutting, Goat rising, } \\
\text { Vegetable farming and Cardamom training etc. }\end{array}$ & $\begin{array}{l}\text { Yet not } \\
\text { completed }\end{array}$ \\
\hline
\end{tabular}

Monitoring and Supervision

As per the provision in ESMF following monitoring has been conducted in the road

Table-19: Monitoring and supervision status

\begin{tabular}{|l|l|l|l|}
\hline Monitoring & As per provision & Conducted & Remarks \\
\hline DMC (District Monitoring Committee) Monitoring & 3 & 2 & \\
\hline Bi-Monthly Monitoring & 12 & 7 & \\
\hline CBPM (Community Based Performance Monitoring) & 3 & 2 & \\
\hline
\end{tabular}

Compliance of social safeguard measures from contractor

From consultation with stakeholders, following condition was found. 
Dipak Basnyat \& Buddhi Raj Joshi., Saudi J Eng Technol, Jan. 2020; 5(1): 1-24

Table-20: Compliance of Social safeguard measures by Contractor

\begin{tabular}{|c|c|c|c|c|}
\hline S.N & Activities & Compliance & Non Compliance & Remarks \\
\hline 1 & Use Construction material from approved site & & Non Compliance & \\
\hline 2 & $\begin{array}{l}\text { Reclaim the quarry site and fill up borrow pit after the completion } \\
\text { of the Work }\end{array}$ & $\begin{array}{l}\text { Partially } \\
\text { Compliance }\end{array}$ & & \\
\hline 3 & Keep the bitumen at least $1 \mathrm{Km}$ far from the village/settlement & Compliance & & \\
\hline 4 & Maintain health and sanitation of the labor camp & Compliance & & \\
\hline 5 & Provide health and safety gears to the labors & & & \\
\hline 6 & Keep records of periodic health checkup of labour & & Non Compliance & \\
\hline 7 & $\begin{array}{l}\text { Do not allow haphazard disposal of spoil along hill slopes, } \\
\text { vegetated areas, water bodies and other environmentally sensitive } \\
\text { areas }\end{array}$ & & Non Compliance & \\
\hline 8 & Restrict labors' use of forest products, hunting and poaching & Compliance & & \\
\hline 9 & Avoid use of child labor (below 16 years age) & Compliance & & \\
\hline 10 & Employ as many women laborer as possible in construction & & Non Compliance & \\
\hline 11 & $\begin{array}{l}\text { Contractors have to pay minimum wage fixed by the concerned } \\
\text { district to both male and female labors. }\end{array}$ & & Non Compliance & \\
\hline 12 & Ensure life insurance of the laborers & $\begin{array}{l}\text { Partially } \\
\text { Compliance }\end{array}$ & & \\
\hline 13 & $\begin{array}{l}\text { Relocate public infrastructure such as; electricity pole, telephone } \\
\text { pole, taps, irrigation, etc }\end{array}$ & Compliance & & \\
\hline
\end{tabular}

Gaps and recommendation for future Improvement

\begin{tabular}{|c|c|c|c|}
\hline S.N & Gaps & Recommendation & Remarks \\
\hline 1. & Geometric design of the road was not as per design standards & $\begin{array}{l}\text { Widening of curve section by cutting uphill side } \\
\text { and/or inserting retaining wall in downhill side, } \\
\text { replacing sharp curve with hair pin bends. }\end{array}$ & \\
\hline 2. & $\begin{array}{l}\text { Contractor doesn't deploy his key personal (Contract manager, } \\
\text { site engineer, lab technician) as mention in contract } \\
\text { documents. }\end{array}$ & $\begin{array}{l}\text { Don't pay the mobilization amount until the key } \\
\text { personal present at site. }\end{array}$ & \\
\hline 3. & Contractor laboratory is not established at site & & \\
\hline 4. & $\begin{array}{l}18 \text { months project was completed in } 36 \text { months by extending } \\
\text { project period into } 3 \text { times. Failure to complete project in time }\end{array}$ & $\begin{array}{l}\text { Ask contractor for revised work program by } \\
\text { increasing their manpower, material and } \\
\text { equipment to complete the project into stipulated } \\
\text { time frame. }\end{array}$ & \\
\hline 5. & $\begin{array}{l}\text { OSH cost is not included in BOQ. So difficult to comply on } \\
\text { site }\end{array}$ & $\begin{array}{l}\text { provide } 2-3 \% \text { of total estimated cost for OSH and } \\
\text { labor camp }\end{array}$ & \\
\hline 6. & $\begin{array}{l}\text { Only 55\% of environmental cost was completed. Reason is not } \\
\text { performing the works by LRUC because of the profit motive. }\end{array}$ & $\begin{array}{l}\text { Provision should be made to break the contract } \\
\text { with LRUC and contract with other parties. }\end{array}$ & \\
\hline 7. & $\begin{array}{l}\text { Land acquisition was taken just only formation width } \\
\text { difficulties for further extension of width. And acquisition } \\
\text { amount is only } 5000 \text { for land owner which is not sufficient. }\end{array}$ & $\begin{array}{l}\text { At least right of way should be taken for land } \\
\text { acquisition so that further intervention should be } \\
\text { easy. Land acquisition amount should be } \\
\text { increased and justified. }\end{array}$ & \\
\hline 8. & $\begin{array}{l}\text { Maintenance of road after completion of works was not done } \\
\text { due to which road deterioration was increased day by day, } \\
\text { drain blockage in different section grass and bushes covered } \\
\text { the drain and road surface. }\end{array}$ & $\begin{array}{l}\text { Need of routine and recurrent maintenance } \\
\text { immediately. }\end{array}$ & \\
\hline 9. & $\begin{array}{l}\text { Quantity and cost estimated for safety management is not } \\
\text { sufficient. Delineator post and traffic sign needed in different } \\
\text { place. Safety barrier, safety reflector needed. }\end{array}$ & $\begin{array}{l}\text { Sufficient budget allocated for Traffic safety } \\
\text { management. }\end{array}$ & \\
\hline
\end{tabular}

\section{Construction site monitoring and reporting through CSM apps}

SNRTP developed CSM apps for supporting a comprehensive reporting system. It is envisioned that the system will have a central data repository and the districts will logged into the server for the data entry and generation of relevant reports. CSM is the Real time, location monitoring system, monitoring from mobile, based on GPS and Web, works in android platform devices.
The field visit report with photo/ videos is stored road wise and district wise in RuTIMS webpage. Any registered CSM user can view the auto generated report finalized by the recorder. It was useful for remote tracking of progress and quality of works. Even a general internet user can view the frequency of visits, overall status of CSM usage by users and districts 

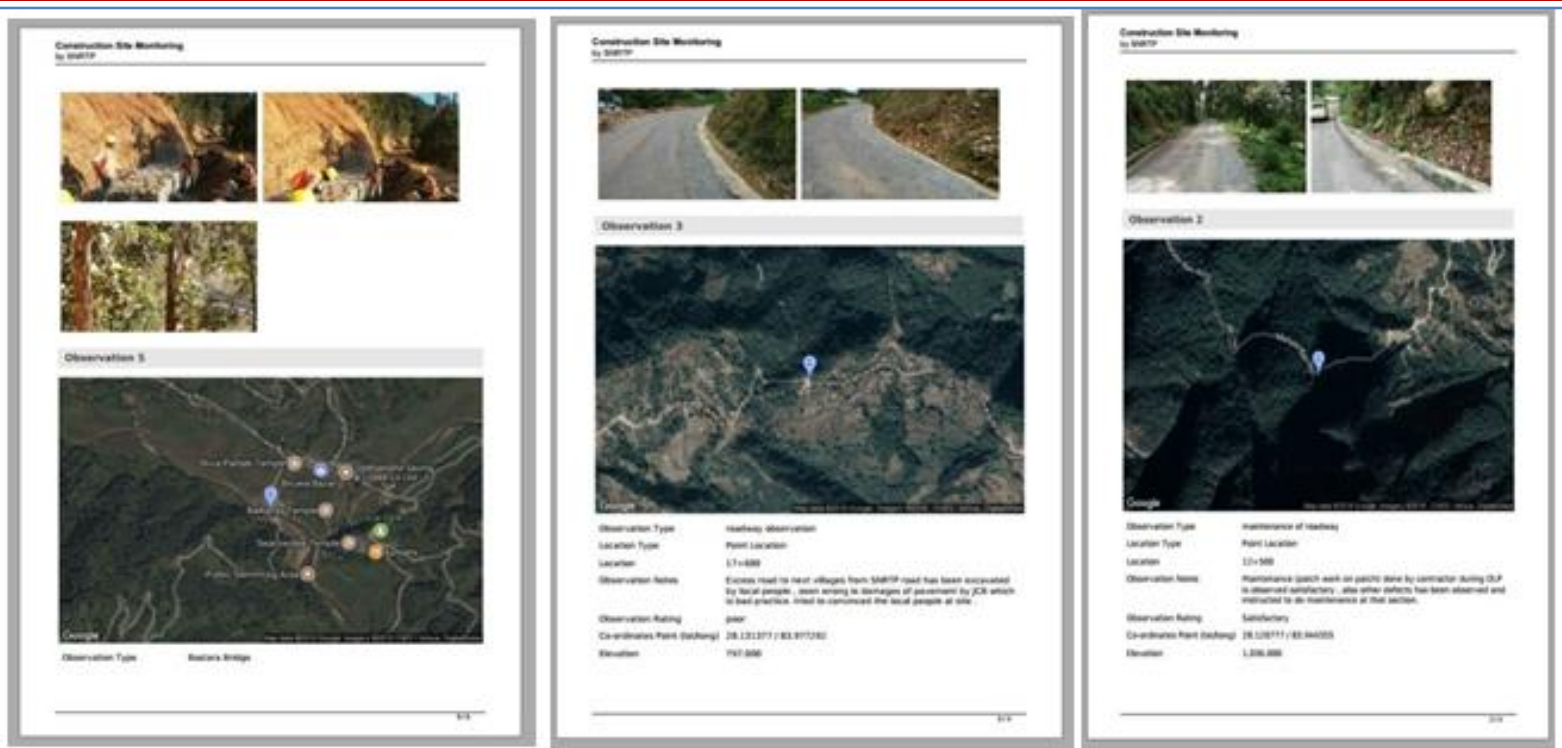

Fig-5: Sample of Uploaded CSM apps

\section{Orientation and Awarness program}

District Technical office, syangja organized a campaign to improve the safety and health of workers and end child labour.The campaign aims to secure working environments for all workers and ending all forms of child from working site.Many factors can increase vulnerability to OSH risks, such as their physical and psychological stage of development, lack of work experience and lack of training, limited awareness of work-related hazards and a lack of bargaining power that can lead workers to accept dangerous tasks or jobs with poor working conditionsa and safety. The program benefits to the labour about the importance and uses of safety tools and equipment, able to tackle with the minor accident and lowering the risk and basic training on first aid.
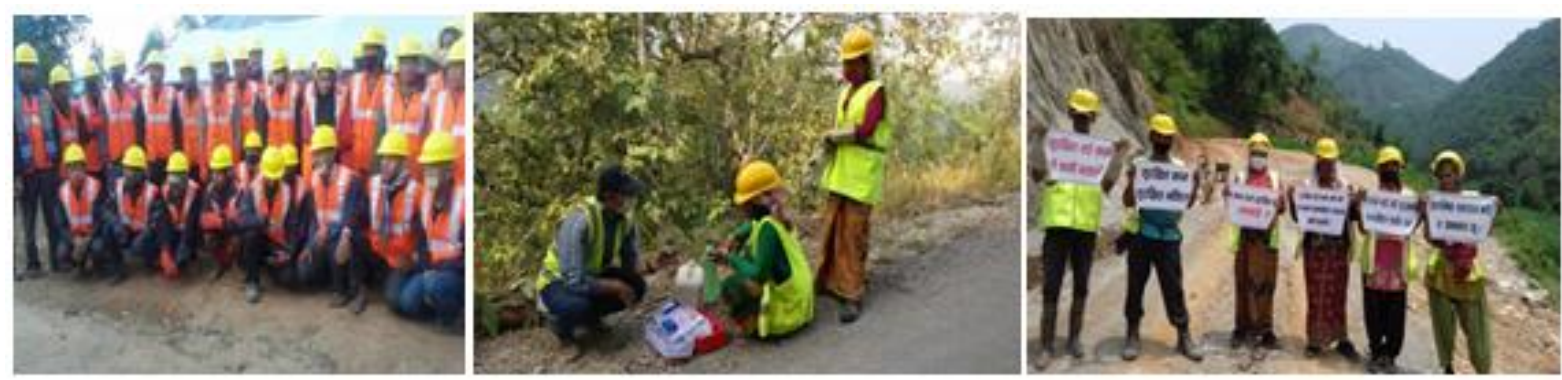

Fig-6: Awareness program on Occupational Safety and Health

\section{Project Performance Evaluation through Spider Chat}

After Analysis of different parameters of the project, detail review of all these parameters was done from Expert (Client, consultant and Contractor) and score was given to each and every parameter. Separate sheet distributed to the expert where different parameters of the project are included and score range is specified from 0-10. From the average score spider charts was drawn which visualize performance of the project.

\section{CONCLUSION}

Government of Nepal with support of World Bank implemented SNRTP project for strengthening rural road to bring the road to an all-weather maintainable standard. Badkhola-Takshar-Dulegaunda road was completed on $28^{\text {th }}$ May 2018 on ottaseal standard. Strong supervision and monitoring mechanism was established by the project to achieve standard quality works and success of the project. Assessment of the project represents evaluation of the project after its completion, analyzing the actual, as against the projected estimates in respect of time, cost and quality specifications.

The conclusion of the study based on the finding drawn from detail analysis of the project. These conclusions are followed by recommendation so as to address the compliance for maintaining the road parameters in the level of prescribed design standards for future project implementation. Compliance with geometric parameters was lagging in BadkholaTakshar-Dulegaunda road. From the field observation at different section of the road, it was found that Road curve, gradient, super elevation, carriage way were not according to the prescribed design standard. 
Dipak Basnyat \& Buddhi Raj Joshi., Saudi J Eng Technol, Jan. 2020; 5(1): 1-24

Traffic safety management of BadkholaTakshar road project was found very poor due to low cost allocation. NPR 5, 000, 00.00 was allocated for 10 KM section. Traffic sign, delineator post installed in road is not sufficient. 25 no of traffic sign, 100 delineator post, 4 Safety reflector on sharp bends, and safety barriers on 3 places at stiff slop were required for proper safety management.

Foot path, street lights, waiting shed was not observed. Time overrun is the major issue of the project. The project was completed after 35 months as per mentioned in contract which was 18 months behind the original completion date. Road maintenance was found poor. The surface deterioration rate is increase day by day, landslide from the slop blocked the drain in many place and water flow over the road, vegetation from both side of the road cover the road surface. Monitoring, reporting, and evaluation were made effective by the use of Construction site monitoring (CSM) apps. This is the best part of the project.

Only $55 \%$ progress was achieved on allocated environmental budget. Contractor and LRUC failed to execute the environmental protection works such as tree plantation, slope protection, erosion control works etc. Partially compliance were found on environmental parameters, from the analysis of Tipping site management , Quarry site management , Bioengineering works, Crusher site management. Occupational safety and Health (OSH) and labor camp management of Badkhola-Takshar road was found satisfactory, instead of allocating budget in BOQ.

Voluntary land donation from land owner was the great achievement of the project. Project existent was difficult without it; it is a great co-ordination between DTO, Project and local community. This project shows that development without local people participation would not sustainable until and unless people should feel the project constructed for their wellbeing. Bimonthly monitoring, Project monitoring from District monitoring committee (DMC) and Community based performance monitoring (CBPM) were not compliance as provision in ESMF. Provision for training provided for project affected people as per Vulnerable community development plan (VCDP) and Gender action plan (GAP) were not compliance.

\section{REFERENCE}

1. SNRTP, ESMF. (2015). Environmental and Social Management Framework(ESMF)(Revised), Project for Strengthening the National Rural Transport Program (SNRTP), Available at <URL:http://snrtp.gov.np/snrtp/wpcontent/uploads/2016/07/Approved-ESMFSNRTP.pdf > [Accessed 5 August 2018]

2. DoLIDAR. (2016). Project Operations Manual(Version-2)Project for Strengthening the National Rural Transport Program (SNRTP),
Available at < http://snrtp.gov.np/snrtp/wpcontent/uploads/2016/07/ SNRTP-Revised-POMApproved-on-14-April.pdf> [Accessed on August 2, 2018]

3. DOLIDAR. (2017). "occupational safety andhealth guidelines" Available at < http://snrtp.gov.np/snrtp/wpcontent/uploads/2017/06/OSH-GUIDELINES.pdf] [Accessed on August 25, 2018]

4. Sharma, D. (2013). status paper on development of Asian Highway Routes Nepal , 2013, Fifth Meeting of the Working Group on the Asian Highway and Asian Highway Investment Forum Bangkok, Thailand, 7 to 9 October 2013, Available at < https://www. unescap.org/sites/default/files/Nepal_1.pdf -2-Oct2018> [Accessed on October 2, 2018]

5. Thu, A.N., Visuth, C. (2013). A Practical list of criteria for evaluating construction project success in developing country, Available at < http://seednet.org/wp-content/uploads/2015/12/a-practicallist-of-criteria-for-evaluating-construction-projectsuccess-in-developing-countries.pdf $>$ [assessed on $10^{\text {th }}$ September 2018]

6. Karki, K., Poudel, P., Rothchild, J., Pope, N., Bobin, N. C., Gurung, Y., \& Sherpa, L. (2017). Scoping review and preliminary mapping menstrual health and hygiene management in Nepal. Lalitpur, Nepal: Population Services International Nepal.

7. Tabish, S. Z. S., \& Jha, K. N. (2011). Identification and evaluation of success factors for public construction projects. Construction Management and Economics, 29(8), 809-823.

8. Khosravi, S., \& Afshari, H. (2011, July). A success measurement model for construction projects. In International Conference on Financial Management and Economics IPEDR (Vol. 11, pp. 186-190). IACSIT Press Singapore.

9. Al-Tmeemy, S. M. H. M., Abdul-Rahman, H., \& Harun, Z. (2011). Future criteria for success of building projects in Malaysia. International Journal of Project Management, 29(3), 337-348.

10. Ahadzie, D. K., Proverbs, D. G., \& Olomolaiye, P. O. (2008). Critical success criteria for mass house building projects in developing countries. International Journal of project management, 26(6), 675-687.

11. Menches, C. L., \& Hanna, A. S. (2006). Quantitative measurement of successful performance from the project manager's perspective. Journal of construction engineering and management, 132(12), 1284-1293.

12. Bryde, D. J., \& Robinson, L. (2005). Client versus contractor perspectives on project success criteria. International Journal of project management, 23(8), 622-629.

13. Lombard, S. M., \& Kirchmer, C. J. (2004). Guidelines for preparing quality assurance 
project plans for environmental studies. Environmental Assessment Program.

14. Halwatura, R. U., \& Ranasinghe, N. P. N. P. (2013). Causes of variation orders in road construction projects in Sri Lanka. ISRN Construction Engineering, 2013.

15. Trowers., \& Hmlins, A. (2016). Projects and construction Liquidated damages in construction contracts in the Gulf, Available at <https://www.trowers.com/uploads/

Files/Liquidated_

damages_in_construction_contracts_in_the_Gulf.p df $>$ [assessed on $7^{\text {th }}$ August 2018]

16. ADB, June. (2018). Price adjustmentguidance note on procurement. Available at < https://www.adb.org/sites/default/files/procurement -price-adjustment.pdf $>$ [assessed on $8^{\text {th }}$ August 2018]
17. Damian McNair. (2016). Australia: Defects Liability Period: an Introduction International Best Practice in Project and Construction Agreements, http://www.mondaq.com/australia/x/219302/Buildi ng+Construction/Defects+Liability+Period+an+Intr oduction

18. DoLIDAR, February. (2018). Revised specification, SNRTP, Available at <http://snrtp. gov $. n p / s n r t p / w p-$

content/uploads/2018/02/Revised-

Specification_February-06_2018.pdf> [Accessed on August 25, 2018]

19. DOR, July. (2001). Standard specification for road and bridge, Available at < http://dor.gov.np/ home/ publication/ standard-specification-of-roads-andbridges/standard-specifications-for-road-andbridge-works-2-73> [Accessed on August 10, 2018] 